\title{
1 Estimating movement rates between Eurasian and North American birds that are vectors
}

2 of avian influenza $(\mathrm{AI})$

4 Fern Spaulding ${ }^{1,2}$, Jessica F. McLaughlin ${ }^{3}$, Travis C. Glenn ${ }^{4}$, Kevin Winker ${ }^{1,2}$

$6 \quad{ }^{1}$ University of Alaska Museum, University of Alaska Fairbanks, Fairbanks, AK 99775, USA

$7 \quad{ }^{2}$ Department of Biology and Wildlife, University of Alaska Fairbanks, AK 99775, USA

$8{ }^{3}$ Sam Noble Oklahoma Museum of Natural History, University of Oklahoma, Norman, OK

973072, USA

$10{ }^{4}$ Department of Environmental Health Science, University of Georgia, Athens, GA 30602, USA

11

12 Corresponding author: Fern Spaulding; frspaulding@alaska.edu 


\section{$14 \quad 1.1$ Abstract}

15 Avian influenza (AI) is an emerging zoonotic disease that will likely be involved in future

16 pandemics. Because waterbird movements are difficult to quantify, determining the host-specific

17 risk of Eurasian-origin AI movements into North America is challenging. We estimated relative

18 rates of movements, based on long-term evolutionary averages of gene flow, between Eurasian

19 and North American waterbird populations to obtain bidirectional baseline rates of the

20 intercontinental movements of these AI hosts. We used population genomics and coalescent-

21 based demographic models to obtain these gene-flow-based movement estimates. Inferred rates

22 of movement between these populations varies greatly among species. Within dabbling ducks,

23 gene flow, relative to effective population size, varies from $\sim 3-24$ individuals/generation

24 between Eurasian and American wigeons (Mareca penelope - M. americana) to 100-300

25 individuals/generation between continental populations of northern pintails (Anas acuta). These

26 are evolutionary long-term averages and provide a solid foundation for understanding the relative

27 risks of each of these host species in potential intercontinental AI movements. We scale these

28 values to census size for evaluation in that context. In addition to being AI hosts, many of these

29 species are also important in the subsistence diets of Alaskans, increasing the risk of direct bird-

30 to-human exposure to Eurasian-origin AI virus. We contrast species-specific rates of

31 intercontinental movements with the importance of each species in Alaskan diets to understand

32 the relative risk of these taxa to humans. Greater scaup (Aythya marila), mallard (Anas

33 platyrhynchos), and northern pintail (Anas acuta) were the top three species presenting the

34 highest risks for intercontinental AI movement both within the natural system and through

35 exposure to subsistence hunters. These directly comparable, species-based intercontinental 
36 movement rates and relative risk rankings should help in modeling, monitoring, and mitigating

37 the impacts of intercontinental host and AI movements.

38

39 Keywords: avian influenza, Beringia, waterfowl, gene flow, subsistence harvest, vector species,

40 Alaska

41 


\subsection{Introduction}

43 Avian influenza (AI) is an emerging zoonotic disease and will likely be involved in future

44 pandemics (Webster et al., 1992; Ferguson et al., 2006; Cooper et al., 2006; Sellwood et al.,

45 2007). AI research and surveillance has demonstrated the exchange of viruses between Eurasia

46 and North America through migratory birds that occur across the Beringia region of the North

47 Pacific Ocean (Pearce et al., 2009; Ramey et al., 2010, 2018; Reeves et al., 2013, 2018). Beringia

48 (Fig. 1) encompasses a large geographic area, and many birds migrate seasonally here to breed.

49 Aquatic birds, such as waterfowl and shorebirds, are often asymptomatic carriers of the disease,

50 indicating that they are well adapted to this pathogen and serve as a natural reservoir (Horimoto

51 \& Kawaoka, 2001). Winker \& Gibson (2010) estimated that $\sim 1.5-2.3$ million birds that are likely

52 vector species of AI migrate from Eurasia across Beringia to their breeding grounds in Alaska

53 every year. This large overlap of Eurasian and North American migration systems causes

54 extensive seasonal contact between these lineages and populations, resulting in a potential for

55 virus movements into and out of North America (Winker et al., 2007; Flint et al., 2009). This

56 vast number of seasonal migrants is often underappreciated when modeling AI introduction into

57 North America (Hinshaw et al., 1980, Donis et al., 1989; Webster et al., 1992; Böning-Gaese et

58 al., 1998; Kilpatrick et al., 2006; Rappole et al., 2006; Winker et al., 2007; Winker \& Gibson,

59 2010). International borders and vast areas of remote land make accurate estimates of

60 intercontinental AI host movements difficult. Yet knowing the degree of these movements

61 between Eurasia and North America is critical to understanding intercontinental transmission of

62 AI viruses.

63 In addition to being potential vectors of intercontinental virus transport, many of these

64 waterfowl and shorebird species are a common staple in the subsistence diets of many Alaskans. 
65 Waterfowl in particular account for a large proportion of annual harvest, making up approximately $85 \%$ of migratory birds taken for subsistence in Alaska (Naves \& Keating, 2017).

67 Many of these birds are possible carriers of AI, including the highly pathogenic avian influenza

68 (HPAI) of Eurasian-origin that has been detected in Alaskan populations of waterfowl (e.g.

69 H9N2, Ramey et al., 2015), and AI viral dispersal across Beringia is not a rare occurrence

70 (Ramey et al., 2018). Extensive human contact with wild populations of waterfowl during

71 hunting might cause AI exposure, a possibility supported by the detection of antibodies in

72 humans to influenza virus subtypes (i.e., H11) found only in wild birds (Gill et al., 2006).

73 Hunters will often process harvested birds themselves while in the field without using gloves or

74 personal protective equipment (Dishman et al., 2010). By processing an influenza-infected duck,

75 a hunter might be exposed to virus-laden mucosa and excretions (i.e., nasal or fecal) in addition

76 to blood, tissues, and other body fluids (Brown et al., 2007; Siembieda et al. 2008; Dishman et

77 al., 2010). Because waterfowl are an important subsistence food for Alaskans, contact while

78 handling and processing these birds is a potential risk factor for direct bird-to-human

79 transmission (Gilsdorf et al., 2006; Yamamoto et al., 2010; Dórea et al., 2013).

80 In this study, we used population genomics, using ultraconserved elements (UCEs) as a

81 sequenced subsampling of the genome, to improve rough estimates (Winker \& Gibson, 2010) of

82 intercontinental AI host movements among key waterbird species to better understand the natural

83 host-virus, movement-transmission landscape in Beringia. Given Alaska's proximity to Eurasia,

84 we also contrast these estimates with the importance of each species in Alaskan diets to

85 understand the relative risk of these taxa directly to human consumers. This information can

86 enable subsistence hunters to selectively harvest species that have a lower potential risk of 
87 carrying Eurasian-origin HPAI. These relative risk rankings should help in modeling,

88 monitoring, and mitigating the impacts of intercontinental host and AI movements.

\section{$89 \quad 1.3$ Materials and Methods}

\section{$90 \quad$ 1.3.1 Sampling and laboratory}

91 Our samples consist of high-quality, vouchered tissue samples from wild birds of

92 Eurasian and North American origin (Table S1). Our study design includes pairwise comparisons

93 of populations, subspecies, and species, because taxonomy is not a reliable indicator of

94 intercontinental levels of gene flow (Humphries \& Winker, 2011; Peters et al., 2012,

95 McLaughlin et al., 2020). We sampled the following numbers of individuals for each vector

96 species: 10 northern pintail (Anas acuta), 12 mallard (Anas platyrhynchos), 10 greater scaup

97 (Aythya marila), 10 common eider (Somateria mollissima), and 9 common and Wilson's snipe

98 (Gallinago gallinago - G. delicata). We also incorporated the gene flow rates obtained by

99 McLaughlin et al. (2020) which include: green-winged teal (Anas crecca crecca - A. c.

100 carolinensis), long-tailed duck (Clangula hyemalis), and Eurasian and American wigeons

101 (Mareca penelope - M. americana). Using UCEs as a sequence-based subsampling of the

102 genome allows us to examine thousands of orthologous loci (Faircloth et al., 2012), and it has

103 been shown that, in general, relatively small sample sizes are sufficient when using coalescent

104 methods to estimating population demographics (Felsenstein, 2005; Nazareno et al., 2017;

105 McLaughlin \& Winker, 2020). Here, we are particularly interested in levels of gene flow $(\mathrm{m})$,

106 which when using our methods of analysis appear to be relatively consistent even when sample

107 sizes vary (McLaughlin \& Winker, 2020). Therefore, we consider our sample sizes to be

108 adequate for the questions we pose. DNA extractions followed standard protocol for animal

109 tissues using the QIAGEN DNeasy Blood + Tissue Extraction Kit (QIAGEN, 2006). Dual- 
110 indexed DNA libraries were prepared and quantified using Qubit fluorimeter (Invitrogen, Inc.,

111 Carlsbad, CA, USA). The samples were enriched for 5,060 ultraconserved element (UCE) loci

112 using the Tetrapods-UCE-5Kv1 kit from MYcroarray following version 1.5 of the UCE

113 enrichment protocol and version 2.4 of the post-enrichment amplification protocol

114 (http://ultraconserved.org/). The resulting pool was sequenced using a paired-end 150 (PE150)

115 protocol on an Illumina HiSeq 2500 using three lanes (Illumina, Inc., San Diego, CA, USA;

116 UCLA Neuroscience Genomics Core).

\section{$117 \quad$ 1.3.2 Bioinformatics}

118 Raw and untrimmed FASTQ sequence data that contained low-quality bases were

119 removed using Illumiprocessor (v.2.0.6; Faircloth, 2013). We built UCE reference sequences for

120 each vector species by combining sequence read files (read1 plus singletons and read2) from two

121 individuals (resulting in one read 1 and one read 2 file). We used the program Trinity (v.2.4.0;

122 Grabherr et al., 2011) to assemble these reads de novo on the Galaxy platform (v.2.4; Afgan et

123 al., 2016), found and extracted UCE loci from this assembly using PHYLUCE (v.1.5.0;

124 Faircloth, 2016) by matching the contigs to the probes set used, and then saved the resulting

125 sequences as a reference FASTA. SNPs within the reference were coded using IUPAC codes.

126 Our bioinformatics pipeline focused on the package PHYLUCE, which calls many dependencies

127 and identifies conserved orthologous loci that are then used as our reference set of UCE loci to

128 call individual variants. Briefly, individual read1 (plus singletons) and read2 files were mapped

129 to the taxon-specific reference and indexed using BWA-MEM (v.0.7.7; Li \& Durbin, 2009; Li,

130 2013) and SAMtools (v.0.1.19; Li et al., 2009). Next, PICARD (v.1.106;

131 http://broadinstitute.github.io/picard) was used to clean the alignments, add read group header

132 information, and remove PCR and sequencing duplicates. SNPs were called for each individual 
133 against the reference sequence using Genome Analysis Toolkit module UnifiedGenotyper

134 (GATK, v.3.3.0; McKenna et al., 2010). GATK was also used to call and realign around indels,

135 call and annotate SNPs, filter SNPs around indels, and then restrict data to high-quality SNPs.

136 VCFtools (v.0.1.13; Danecek et al., 2011) was used to filter the high-quality SNPs to create a

137 complete matrix (all individuals represented at all loci) with a minimum genotype quality

138 (Phred) score of 10.0 (which equates to $90 \%$ confidence). The high-quality VCF was then

139 thinned to $1 \mathrm{SNP} /$ locus and made biallelic. We used BLASTn on NCBI to identify sex-linked

140 loci (Z-linked) using our high-quality reference data of confidently surveyed loci, and resulting

141 hits for Z-linked loci were then removed using a custom script (find_chromy v.1.2;

142 https://github.com/jfmclaughlin92/beringia_scripts/). Our thinned, biallelic VCF with Z-linked

143 loci removed was used for our demographic analyses to estimate movement (i.e., gene flow).

$144 \quad$ 1.3.3 Demographic analyses to estimate gene flow

145 Diffusion Approximations for Demographic Inference ( $\delta a \delta i, v .1 .7 .0$; Gutenkunst et al.,

146 2009) was used to estimate demographic parameters under best-fit models of pairwise

147 divergence. Note that in population genomics models, "migration" equals gene flow and is not

148 related to the seasonal migration of individuals. To find a best-fit model of demographic history,

149 we tested eight divergence models (Fig. S1): A) no divergence (neutral, populations never

150 diverge); B) split with no migration (divergence without gene flow); C) split with migration

151 (divergence with gene flow that is bidirectionally symmetric, 1 migration parameter); D) split

152 with bidirectional migration (divergence with gene flow that is bidirectionally asymmetric, 2

153 migration parameters); E) split with exponential population growth, no migration; F) split with

154 exponential population growth and migration; G) secondary contact with migration (1 migration 
155 parameter); and $\mathrm{H}$ ) secondary contact with bidirectional migration (2 migration parameters). The

156 scripts for these models are available here: https://figshare.com/s/e75158104c7896fa79e7.

157 For each pairwise comparison, we ran a series of optimization runs that consisted of

158 running the model repeatedly to fine-tune model parameters. Following optimization, the best

159 five log-likelihood scores from each set of subsequent runs were averaged to summarize that

160 model. We used the Akaike Information Criterion (AIC; Akaike, 1974; Burnham \& Anderson,

161 2004) to determine the best-fit model. Once the best-fit model was determined, it was run at least

16215 times to obtain demographic parameter estimates, and we used these estimates from the best-

163 fit model's top three runs to calculate biological estimates. Then the model was bootstrapped to

164 provide a 95\% confidence interval around each demographic parameter. To convert the best-fit

165 model's demographic parameters to biologically relevant values, we determined generation time

166 from the literature and estimated substitution rates (Table S2) using BLASTn to compare each

167 reference FASTA to a related avian genome with a fossil-calibrated node (Claramunt \& Cracraft,

168 2015). These values were then used with the best-fit model demographic parameter estimates

169 obtained from our analyses to provide estimates of ancestral population size $\left(N_{r e f}\right)$, size of

170 populations $(n u 1, n u 2)$, time since split $(T)$, migration $(M$; gene flow in individuals/generation,

171 derived from the raw model output $m$ ), migration from population 1 into population 2 (derived

172 from $\mathrm{m} 12$ ), migration from population 2 into population 1 (derived from $m 21$ ), and time of

173 secondary contact $\left(T_{s c}\right)$ as appropriate (based on the best-fit model for each pairwise

174 comparison).

$175 \quad$ 1.3.4 Scaling movement, harvest rates, and risk factors

176 Estimates of gene flow from the demographic analysis in $\delta a \delta i$ are based on long-term

177 effective population sizes $\left(N_{e}\right)$, which is nearly always lower than census size in high-latitude 
178 birds (e.g., McLaughlin et al., 2020). These evolutionary average rates of gene flow are not

179 scaled to census size, so they are very conservative, but they are directly comparable to each

180 other. To consider these rates relative to census sizes, estimates of the latter were obtained from

181 population estimates from the U.S. Fish and Wildlife Service (USFWS, 2019) and from

182 Wetlands International (2021). The USFWS combines both greater and lesser scaup (Aythya

183 marila and Aythya affinis) into one census estimate because the two species can be difficult to

184 distinguish. To address this, we used the ratio of greater and lesser scaup obtained from the Bird

185 Conservancy of the Rockies' global population estimates as part of their Partners in Flight,

186 Avian Conservation Assessment Database (ACAD, 2020). We applied this ratio to the USFWS

187 (2019) census estimate of "scaup" to obtain a census estimate for greater scaup alone. We used

188 the proportion of gene flow ( $M$, in individuals/generation) relative to effective population size

$189\left(N_{e}\right)$ to scale our estimates of long-term gene flow up to approximately estimate contemporary

190 gene flow by multiplying this proportion by census size: ( $M_{\text {Eurasia }} / N_{e}$ North America ${ }^{*}$ census size).

191 Subsistence harvest rates in Alaska were obtained from Naves \& Otis (2017) and Naves

192 \& Keating $(2018,2020)$. Some subsistence species were not categorized with a species name, so

193 the species categorized as "Teal" were used for green-winged teal (Anas crecca crecca - A. c.

194 carolinensis), "Scaup" for greater scaup (Aythya marila), and "Small Shorebird" for common

195 and Wilson's snipe (Gallinago gallinago - G. delicata). We calculated the average annual

196 harvest for each vector species across the years 2016, 2017, and 2018. To calculate a relative risk

197 of potential exposure of Eurasian-origin AI virus to subsistence users, we estimated the number

198 of individuals harvested of Eurasian origin given $\left(M / N_{e}\right)$ and annual harvest $\left(M_{\text {Eurasia }} / N_{e}\right.$ *annual

199 harvest). Given high variation in AI infection rates (e.g., annual, seasonal, geographic), we did 200 not add this as a variable. 


\subsection{Results}

\subsubsection{Estimated rates of gene flow}

The best-fit models for our demographic analyses in $\delta a \delta i$ found gene flow present in all

204 pairwise comparisons (Table S3). In half of our comparisons (four species) the AIC analyses

205 showed that some models fit the data similarly well, yielding a best-fit model and a runner-up

206 model that was not statistically worse. These cases were in green-winged teal (Anas crecca

207 crecca - A. c. carolinensis), greater scaup (Aythya marila), common eider (Somateria

208 mollissima), and common and Wilson's snipe (Gallinago gallinago - G. delicata). These runner-

209 up models occurred between split-with-migration models and secondary-contact models (Table

210 S3). For demographic analyses we chose the best-fit model to be the one with the lowest AIC

211 value, a $\triangle \mathrm{AIC}=0$, and a weighted $\mathrm{AIC}=1$ (Tables $\mathrm{S} 3, \mathrm{~S} 4)$. The best-fit models were: split with

212 symmetric migration (Fig. S1C) for northern pintail (Anas acuta), mallard (Anas platyrhynchos),

213 and the greater scaup (Aythya marila); split with bidirectional (asymmetric) migration (Fig. S1D)

214 in common eider (Somateria mollissima), and the common and Wilson's snipe (Gallinago

215 gallinago - G. delicata) contrast; secondary contact with symmetric migration (Fig. S1G) in

216 long-tailed ducks (Clangula hyemalis); and secondary contact with bidirectional migration (Fig.

$217 \mathrm{~S} 1 \mathrm{H}$ ) for green-winged teal (Anas crecca crecca - A. c. carolinensis) and the Eurasian and

218 American wigeon (Mareca penelope - M. americana) contrast. From these best-fit models, the

219 raw demographic parameter output (Table S5) was used to calculate a biological estimate of the

220 long-term average rates of gene flow (Table S6).

$221 \quad$ Estimates for gene flow between Eurasian and North American vector species showed

222 substantial levels of variation in movement (gene flow) between continental populations (Table

223 1). Values of individuals per generation varied across three orders of magnitude (Table 1). The 
224 dabbling ducks—northern pintail (Anas acuta), mallard (Anas platyrhynchos), Eurasian-

225 American wigeon (Mareca penelope - M. americana), and green-winged teal (Anas crecca

226 crecca-A. c. carolinensis) - showed the greatest magnitude of movements. Of these, northern

227 pintail (Anas acuta) had the largest amount of movement (upwards of $\sim 100-300$

228 individuals/generation). The diving and sea ducks-long-tailed duck (Clangula hyemalis),

229 greater scaup (Aythya marila), and common eider (Somateria mollissima)—showed a wide range

230 in their levels of movement. Of these ducks, the greatest magnitude of intercontinental

231 movement occurred in long-tailed ducks (Clangula hyemalis; 24-87 individuals/generation),

232 while the lowest levels occurred in the common eider ( 1-2 individuals/generation; Table 1). Our

233 comparison of common and Wilson's snipe (Gallinago gallinago - G. delicata) showed low

234 levels of movement, with less than 1 individual/generation (Table 1).

235 Estimates of gene flow between Eurasian and North American populations as a

236 proportion of effective population size $\left(N_{e}\right)$ showed the proportion to be small across all species

237 (Table 1). Of all these vector species, greater scaup (Aythya marila) had the highest proportion of

238 movement into North America from Eurasia. The northern pintail (Anas acuta) had the highest

239 proportion of movement into Eurasia from North America.

$240 \quad$ 1.4.2 Relative risks of AI host species

241 Gene flow as a proportion of $N_{e}$ is conservative for contemporary populations, and

242 scaling these values to census population sizes and annual harvest rates should result in more

243 useful numbers for risk assessment. We did these calculations using the data from Table 1 to

244 rank vector species in decreasing order of relative risk of intercontinental AI movement, both

245 within the natural system (gene flow scaled to census size) and in the context of subsistence use

246 (gene flow scaled to harvest rates; Table 2). The top three species in each context (though in 
247 slightly different order between each context) were greater scaup (Aythya marila), mallard (Anas

248 platyrhynchos), and northern pintail (Anas acuta; Table 2). Other species, e.g., green-winged teal

249 (Anas crecca crecca - carolinensis), Eurasian and American wigeons (Mareca penelope -

250 americana), and long-tailed duck (Clangula hyemalis), were intermixed in their rankings.

251 Finally, common eiders (Somateria mollissima) and common and Wilson's snipe (Gallinago

252 gallinago - G. delicata) were equivalently ranked in the two contexts (natural system and

253 subsistence use) and had the lowest relative risk (Table 2).

254 The average annual harvest rates in Alaska (Table 1) show that three taxa, mallard (Anas

255 platyrhynchos), northern pintail (Anas acuta), and Eurasian and American wigeons (Mareca

256 penelope - americana), have the highest rates of harvest. When considering proportions of

257 Eurasian-origin birds, two of these species, the mallard and northern pintail, are ranked numbers

258 two and three (respectively) in relative risk for Asian-origin AI exposure (Table 2). Greater

259 scaup (Aythya marila) has only a moderate level of harvest (Table 1), but when considering the

260 estimated proportion of Asian-origin individuals, it had the highest risk of causing potential

261 Asian-origin AI exposure to subsistence users (Table 2).

$262 \quad 1.5$ Discussion

263 Our study found that levels of intercontinental gene flow in waterbird AI vector species is

264 highly variable. These results provide a solid quantitative framework for among-species contrasts

265 in this AI risk assessment context. We show how population genomics methods can be applied to

266 fill knowledge gaps to help understand the ecology of intercontinental pathogen movements, and

267 to help subsistence users mitigate potential Eurasian-origin AI exposure. Among our sampled

268 species, dabbling ducks overall had the highest rates of intercontinental movement as inferred

269 from long-term average levels of gene flow. Variation in gene flow rates spanning orders of 
270 magnitude among AI vector species makes it clear that all do not pose similar risks of

271 intercontinental virus movement (Table 1), and we are able to provide relative risk rankings

272 among the species studied (Table 2). We note that the variation in movement among vector

273 species could be due to variation in factors such as different life-history characteristics, patterns

274 of dispersal, and behavioral tendencies. Assessments of population connectivity are particularly

275 difficult for species that nest at high latitudes, as they often have large distributions across the

276 annual cycle that span remote (uninhabited) landscapes, further reducing the detectability of

277 dispersal events and the ability to evaluate the magnitudes of movements occurring (Sonsthagen

278 et al., 2011; Talbot et al., 2015; Sonsthagen et al., 2019). Overall, our results showed that these

279 vector species appear to vary by three orders of magnitude in the bird-to-bird natural system and

280 by two orders of magnitude in the human-to-bird subsistence system (Tables 1,2).

281 Contrasting rates of gene flow, census population sizes, and harvest should enable a more

282 fine-tuned approach to AI risk mitigation, monitoring, and surveillance. However, this approach

283 does have limitations. First, we focused on the host movement system rather than on the viruses

284 themselves. Infection rates are highly variable and are dependent on species, year, seasonality,

285 and geographic location (Webster et al., 1992; Dushoff et al., 2004; Altizer et al., 2006; Winker

286 et al., 2007). Because infection rates are highly variable and are dependent on many factors, we

287 did not incorporate them into our assessment of risk ranking. We feel that until those variables

288 can be better developed and understood in this region, the basic attributes of the natural delivery

289 system (e.g., gene flow rates, census sizes) provide a useful initial baseline for relative risk.

290 Gene flow is a measure (in evolutionary time) of contact between populations, and it is not

291 equivalent to annual intercontinental movements of individuals. It does, however, provide an

292 effective long-term metric, comparable among lineages, on which to base intercontinental AI 
293 movement risk assessments. Our estimates of gene flow are based on long-term $N_{e}$, and scaling

294 up to census sizes is not straightforward. Long-term effective population sizes are generally

295 smaller than modern census sizes, but among species the two are only loosely correlated

296 (Roman, 2003). So while we have confidence that the relative rates of gene flow between

297 populations are directly comparable among lineages across evolutionary time, converting those

298 values to numbers of individuals given current census sizes (which themselves are only

299 estimates, e.g., Barclay, 2012) represents an approximation. In addition, rates of gene flow can

300 be affected by partial reproductive isolation between lineages, which would make them lower

301 relative to actual movements. Furthermore, gene flow is an imperfect proxy for AI virus

302 transmission because the latter can occur without host reproduction and can easily occur across

303 species, depending on varying levels of host resistance to AI viruses. Thus, while our analyses

304 provide a robust contrast among co-distributed lineages over the long term in an evolutionary

305 context, annual variation is present and can only be approximated by our scaling to census sizes

306 and harvest rates to estimate risk, and gene flow is not a perfect proxy for virus transmission.

307 Future work could involve pairing the results of this study with AI infection rates in each species

308 for region, season, and year when such information becomes available.

309 Our study provides important details about the vector landscape through which AI viruses

310 must navigate to move intercontinentally in this region. By quantifying the movements of vector

311 species in terms of levels of gene flow and long-term effective population size $\left(N_{e}\right)$, we produce

312 a robust metric enabling direct comparison among lineages that move intercontinentally in

313 Beringia. By scaling these long-term movement rates to census sizes and harvest rates in Alaska

314 (Table 1), we were able to estimate the relative risk that each species poses for Eurasian-origin

315 AI both in the natural virus delivery system and in the Alaska subsistence harvest (Table 2). 
316 These results give subsistence hunters new information that can be used to choose to harvest

317 species with a lower level of intercontinental movement that pose a lower risk of Eurasian-origin

318 AI exposure, rather than harvest species that might pose a higher risk (Fig. 2). Likewise,

319 prioritizing AI surveillance in species with high levels of intercontinental movement might be

320 useful. Our baseline estimates of host-specific movements of AI vector species can be used to

321 model, monitor, and mitigate AI virus movement in the Beringia region.

\section{Acknowledgments}

324 We thank the University of Alaska Museum and the Louisiana State University Museum of

325 Natural Science for loans of tissue specimens and the specimen collectors who made it possible

326 to do this research. We also thank the Kessel Fund for Northern Ornithology and the Friends of

327 Ornithology for financial support, and Brant Faircloth for his input early in the project. This

328 project was funded in part by the the National Science Foundation (DEB-1242267-1242241-

329 1242260), by an Institutional Development Award (IDeA) from the National Institute of General

330 Medical Sciences of the National Institutes of Health under grant number 2P20GM103395, and

331 by the National Institute of General Medical Sciences of the National Institutes of Health under

332 award number RL5GM118990. Naoki Takebayashi and Devin Drown provided helpful

333 comments and feedback on earlier drafts of the manuscript.

335 Data Availability Statement

336 Original sequence data have been deposited in the NCBI Sequence Read Archive (SRA; Table

337 1.S1; projects PRJNA741698, PRJNA741809, and PRJNA393740).

\section{Author Contributions}

340 The study was conceived by Kevin Winker, Travis Glenn, and Brant Faircloth. The data were 341 generated by Travis Glenn and Brant Faircloth. The data were analyzed by Fern Spaulding. The

342 first draft was written by Fern Spaulding. All authors contributed to the final version. 


\subsection{Figures}

Figure 1. Beringia encompasses the region extending from the Russian Far East across the Bering Sea though Alaska to western Canada in North America. Across Beringia, waterbirds are important avian influenza (AI) vectors and are a staple in the rural subsistence diet.

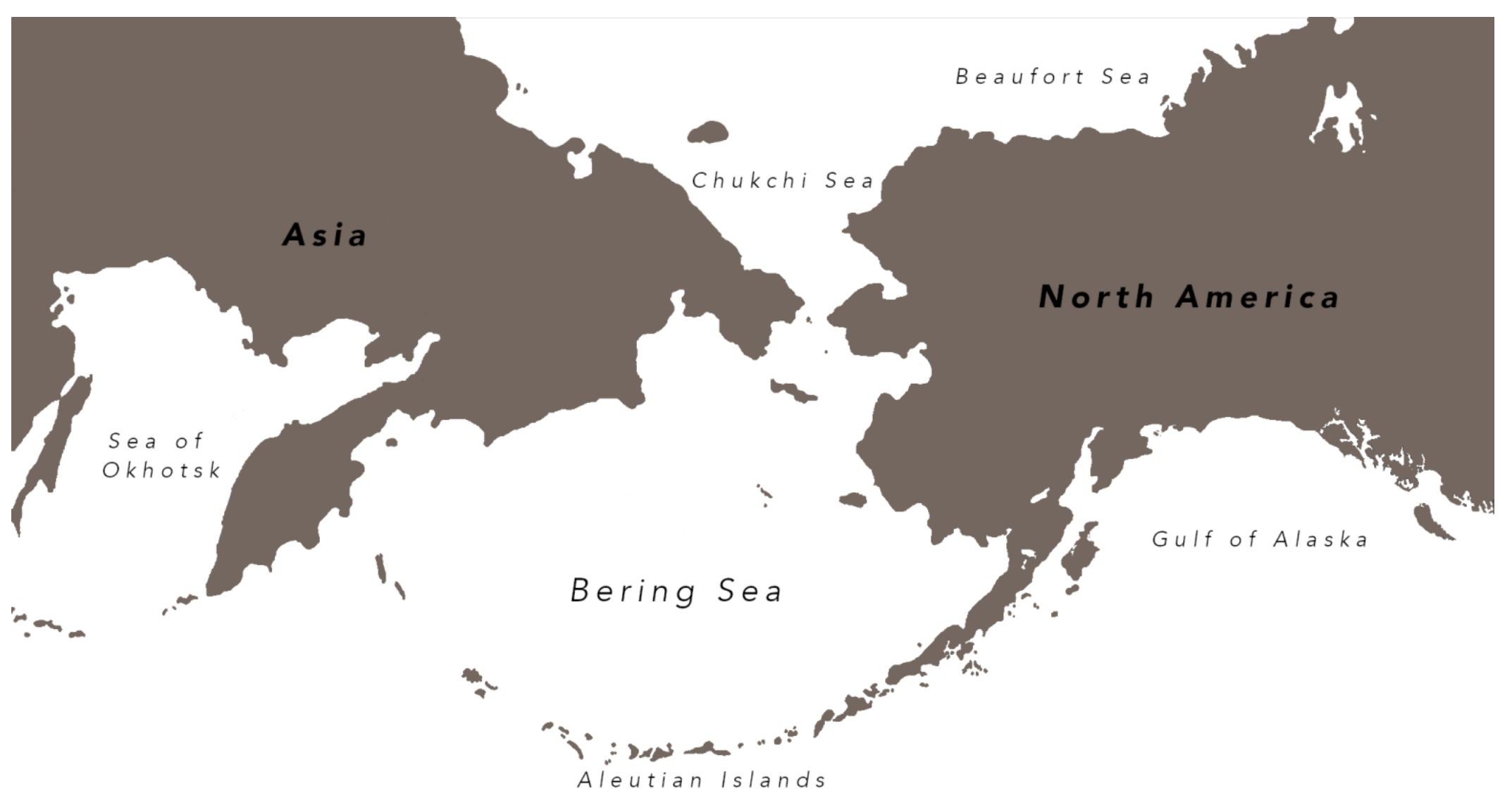


Figure 2. How subsistence hunting could change to mitigate human exposure to Eurasian-origin avian influenza (AI). Species with high levels of intercontinental movement might be less desirable to harvest than species with low to moderate levels of intercontinental movement. A) Current understanding: unknown levels of intercontinental movement make it impossible to determine which species pose a high risk of possible Eurasian-origin AI exposure. B) This study shows intercontinental movements to be high in greater scaup (red), moderate in wigeons (yellow), and low in common eider (green) given the proportion of individuals of Eurasian origin given $\left(M / N_{e}\right)$ and annual harvest (Table 2). With this information, a subsistence hunter can choose to harvest species with lower intercontinental movements at higher rates to lower human risk of potential Eurasian-origin AI exposure. Illustrations from Hines (1963).

A)
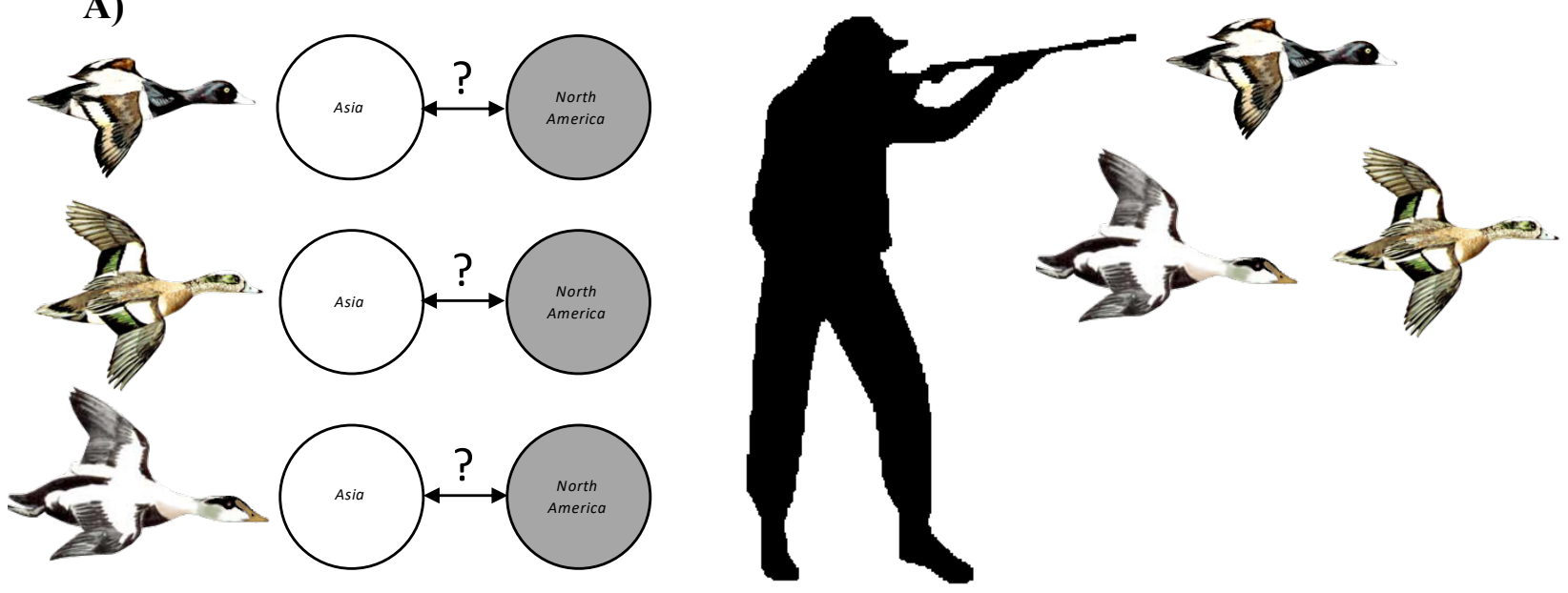

B)
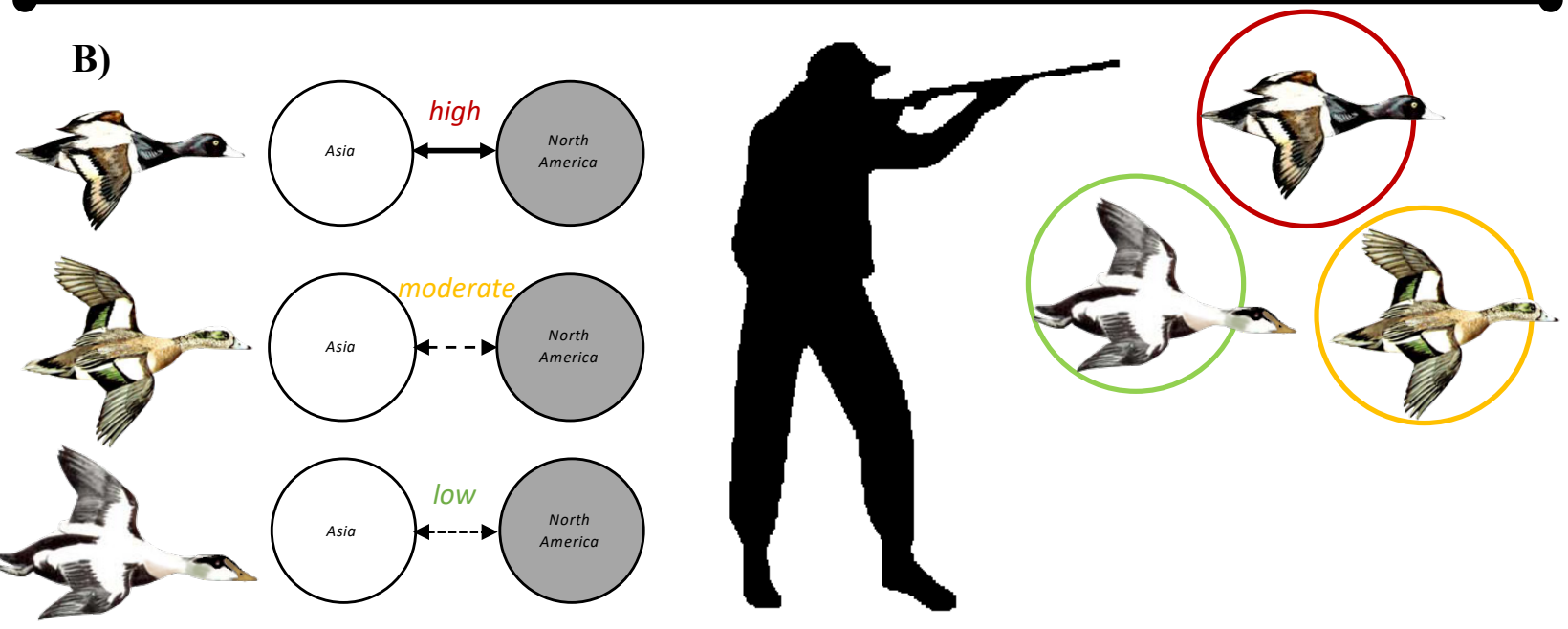


\subsection{Tables}

Table 1. Avian influenza (AI) vector species of birds with estimated rates of gene flow between Eurasian and North American populations (individuals/generation), movement between Eurasian and North American populations as a proportion of effective population size that is experiencing the influx (continent-based $N_{e}$ ), average number of individuals harvested in Alaska (across years: 2016, 2017, and 2018), and estimated census size in across North America. Illustrations were obtained from Hines (1963) and National Geographic Society (1999).

*Gene flow results from McLaughlin et al. (2020)

**Individuals categorized as "Teal" were used for green-winged teal comparison, "Scaup" for greater scaup, and "Small Shorebird" for common and Wilson's snipe.

\begin{tabular}{|c|c|c|c|c|c|c|}
\hline Vector Species & $\begin{array}{l}\text { Gene flow } \\
\text { into } \\
\text { Eurasia } \\
\text { from North } \\
\text { America }\end{array}$ & $\begin{array}{c}\text { Gene flow } \\
\text { into North } \\
\text { America } \\
\text { from } \\
\text { Eurasia }\end{array}$ & $\begin{array}{l}\text { Gene flow } \\
\quad \text { into } \\
\text { Eurasia as } \\
\text { proportion } \\
\quad \text { of } N e\end{array}$ & $\begin{array}{c}\text { Gene flow } \\
\text { into North } \\
\text { America as } \\
\text { proportion of } \\
\quad \mathrm{Ne}\end{array}$ & $\begin{array}{c}\text { Average } \\
\text { Annual } \\
\text { Harvest } \\
\text { in } \\
\text { Alaska }\end{array}$ & $\begin{array}{c}\text { Estimated } \\
\text { Census } \\
\text { Size }\end{array}$ \\
\hline $\begin{array}{l}\text { Northern Pintail } \\
\text { (Anas acuta) }\end{array}$ & $\begin{array}{l}104.32 \\
( \pm 0.14)\end{array}$ & $\begin{array}{l}389.78 \\
( \pm 0.53)\end{array}$ & $9.93 \times 10^{-4}$ & $7.11 \times 10^{-5}$ & 17,949 & $2,300,000$ \\
\hline $\begin{array}{l}\text { Mallard } \\
\text { (Anas platyrhynchos) }\end{array}$ & $\begin{array}{c}54.83 \\
( \pm 0.31)\end{array}$ & $\begin{array}{c}82.70 \\
( \pm 0.47)\end{array}$ & $1.62 \times 10^{-4}$ & $7.10 \times 10^{-5}$ & 19,255 & $9,400,000$ \\
\hline
\end{tabular}


Table 1, continued.

\begin{tabular}{|c|c|c|c|c|c|c|}
\hline $\begin{array}{l}\text { Green-winged Teal* } \\
\text { (Anas crecca crecca- } \\
\text { A. c. carolinensis) }\end{array}$ & $\begin{array}{c}23.31 \\
( \pm 0.63)\end{array}$ & $\begin{array}{c}18.35 \\
( \pm 2.29)\end{array}$ & $1.14 \times 10^{-5}$ & $3.98 \times 10^{-5}$ & $* * 5,224$ & $3,200,000$ \\
\hline $\begin{array}{l}\text { Eurasian and } \\
\text { American Wigeons* } \\
\text { (Mareca penelope- } M \text {. } \\
\text { americana) }\end{array}$ & $\begin{array}{c}24.24 \\
( \pm 0.48)\end{array}$ & $\begin{array}{c}3.17 \\
( \pm 0.56)\end{array}$ & $2.77 \times 10^{-5}$ & $4.14 \times 10^{-5}$ & 10,724 & $2,800,000$ \\
\hline $\begin{array}{l}\text { Long-tailed Duck* } \\
\text { (Clangula hyemalis) }\end{array}$ & $\begin{array}{c}23.84 \\
( \pm 0.43)\end{array}$ & $\begin{array}{l}86.89 \\
( \pm 1.57)\end{array}$ & $7.43 \times 10^{-4}$ & $5.59 \times 10^{-5}$ & 4,537 & $1,000,000$ \\
\hline $\begin{array}{l}\text { Greater Scaup } \\
(\text { Aythya marila })\end{array}$ & $\begin{array}{c}6.96 \\
( \pm 0.22)\end{array}$ & $\begin{array}{c}10.06 \\
( \pm 0.32)\end{array}$ & $6.60 \times 10^{-4}$ & $3.16 \times 10^{-4}$ & $* * 8,763$ & 881,633 \\
\hline $\begin{array}{l}\text { Common Eider } \\
\text { (Somateria } \\
\text { mollissima) }\end{array}$ & $\begin{array}{c}2.14 \\
( \pm 0.15)\end{array}$ & $\begin{array}{c}0.86 \\
( \pm 0.12)\end{array}$ & $3.40 \times 10^{-5}$ & $1.97 \times 10^{-5}$ & 8,534 & $1,297,000$ \\
\hline
\end{tabular}


Table 1, continued.

\section{Common and}

Wilson's Snipe

$0.68 \quad 0.01$

(Gallinago gallinago-

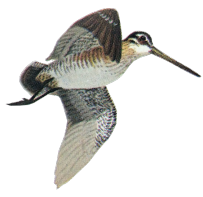

$( \pm 0.04)$

$( \pm 0.05)$

$1.28 \times 10^{-6}$

$1.18 \times 10^{-7}$

$* * 77$

$2,000,000$ 
Table 2. Avian influenza (AI) vector species of birds ranked in decreasing order of their relative risk of AI transmission to North American populations (left column) and to subsistence users (right column). Each entry applies the gene flow estimate from Table 1 to estimate the proportion of census size (left column) or average annual subsistence harvest in Alaska (right column). Illustrations from Hines (1963) and National Geographic Society (1999).

Individuals of Eurasian origin given $\left(M / N_{e}\right)$ and

Vector Species
census size
Individuals of Eurasian origin given $\left(M / N_{e}\right)$ and annual harvest

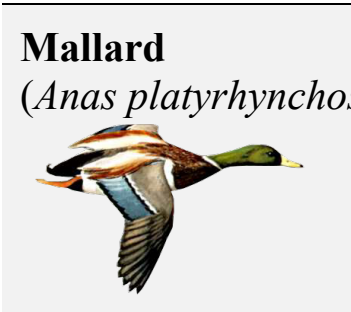

Greater Scaup

(Aythya marila)

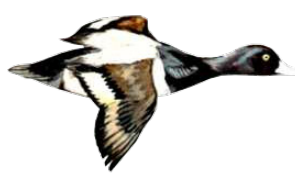

\section{Northern Pintail}

(Anas acuta)

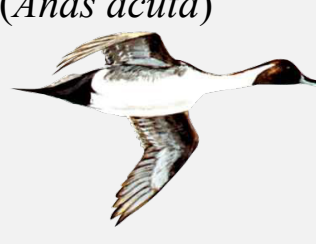

Vector species

Greater Scaup

(Aythya marila)

667.42

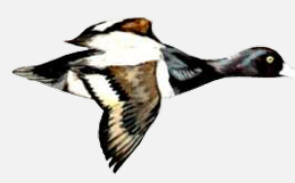

\section{Mallard}

(Anas platyrhynchos)

278.71

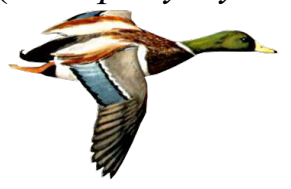

\section{Northern Pintail}

(Anas acuta)

163.63

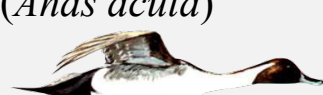

1.28 
Table 2, continued.

Green-winged Teal

(Anas crecca crecca-A. c.

carolinensis)
127.44
Eurasian and American

Wigeons

(Mareca penelope-M.

americana)

0.44

Eurasian and American

Wigeons

(Mareca penelope-M.

americana)

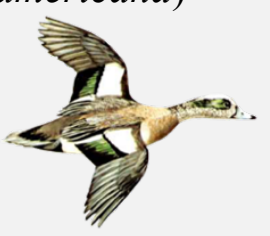

Long-tailed Ducks

(Clangula hyemalis)
115.97

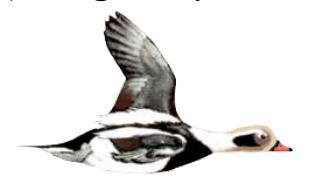

Long-tailed Ducks

(Clangula hyemalis)

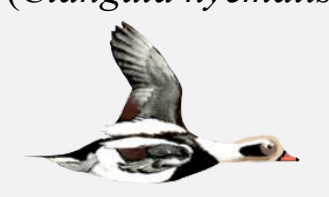

Green-winged Teal

(Anas crecca crecca-A. c. carolinensis)

0.21

23 
Table 2, continued.

\section{Common Eider}

(Somateria mollissima)

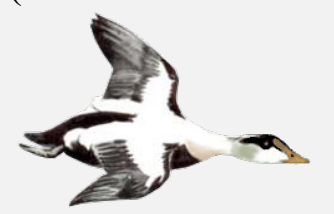

\section{Common Eider}

(Somateria mollissima)

\section{Common and Wilson's Snipe}

(Gallinago gallinago - G.

delicata)

0.16

\section{Common and Wilson's Snipe}

(Gallinago gallinago - G.

delicata)

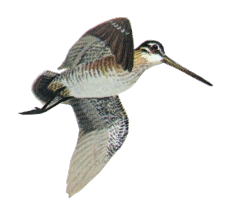




\subsection{References}

Afgan, E., Baker, D., van den Beek, M., Blankenberg, D., Bouvier, D., Čech, M., Chilton, J., Clements, D., Craor, N., Eberhard, C., Grüning, B., Guerler, A., Hillman-Jackson, J., Von Kuster, G., Rasche, E., Soranzo, N., Turaga, N., Taylor, J., Nekrutenko, A., Goecks, J. 2016. The Galaxy platform for accessible, reproducible and collaborative biomedical analyses. Nucleic Acids Res. 44, 3-10.

Akaike H. 1974. A new look at the statistical model identification. IEEE Transactions on Automatic Control. 19, 716-723.

Altizer, S., Dobson, A., Hosseini, P., Hudson, P., Pascual, M., Rohani, P. 2006. Seasonality and the dynamics of infectious diseases. Ecology Letters. 9, 467-484.

Arnold, T.W., Clark, R.G. 1996. Survival and philopatry of female dabbling ducks in southcentral Saskatchewan. The Journal of Wildlife Management, 60, 560.

Avian Conservation Assessment Database and Population Estimates Handbook (ACAD). 2020. https://pif.birdconservancy.org/ Accessed 30 May 2021.

Barclay, J.S. 2012. Status of greater scaup in North America. https://globally-threatened-birdforums.birdlife.org. Accessed on 30 May 2021.

Bellrose, F.C. 1976. Ducks, geese, and swans of North America. Harrisburg, PA: Stackpole Books.

Böning-Gaese, K., González-Guzmán, L.I., Brown, J.H. 1998. Constraints on dispersal and the evolution of the avifauna of the Northern Hemisphere. Evolutionary Ecology. 12, 767783.

Brown, J.D., Stallknecht, D.E., Valeika, S., \& Swayne, D.E. 2007. SUSCEPTIBILITY OF WOOD DUCKS TO H5N1 HIGHLY PATHOGENIC AVIAN INFLUENZA VIRUS. Journal of Wildlife Diseases, 43, 660-667.

Burnham, K.P., Anderson D.R. 2004. Multimodel inference: understanding AIC and BIC in model selection. Sociological Methods \& Research. 33, 261-304.

Claramunt, S., Cracraft, J. 2015. A new time tree reveals Earth history's imprint on the evolution of modern birds. Science Advances. 1, e1501005.

Cooper, B.S, Pitman, R.J., Edmunds, W.J., Gay, N.J. 2006. Delaying the international spread of pandemic influenza. PLoS Medicine. 3, 845-855.

Danecek, P., Auton, A., Abecasis, G., Albers, C. A., Banks, E., DePristo, M. A., ... 1000 Genomes Project Analysis Group. 2011. The variant call format and VCFtools. Bioinformatics. 27, 2156-2158.

Dishman, H., Stallknecht, D., \& Cole, D. 2010. Duck hunters' perceptions of risk for avian influenza, Georgia, USA. Emerging Infectious Diseases. 16, 1279-1281.

Donis, R.O., Bean, W.J. Kawaoka, Y., Webster, R.G. 1989. Distinct lineages of influenza virus H4 hemagglutinin genes in different regions of the world. Virology. 169, 408-417.

Dórea, F. C., Cole, D. J., \& Stallknecht, D. E. 2013. Quantitative exposure assessment of waterfowl hunters to avian influenza viruses. Epidemiology \& Infection. 141, 10391049.

Drilling, N., Titman, R.D. McKinney, F. 2020. Mallard (Anas platyrhynchos), version 1.0. In Birds of the World (S. M. Billerman, Editor). Cornell Lab of Ornithology, Ithaca, NY, USA. 
Dushoff, J., Plotkin, J.B., Levin, S.A., Earn, D.J.D. 2004. Dynamical resonance can account for seasonality of influenza epidemics. Proceedings of the National Academy of Sciences. 101, 16915-16916.

Faircloth, B.C. 2013. Illumiprocessor: a trimmomatic wrapper for parallel adapter and quality trimming. http://dx.doi.org/10.6079/J9ILL.

Faircloth, B.C. 2016. PHYLUCE is a software package for the analysis of conserved genomic loci. Bioinformatics. 32, 786-788.

Felsenstein, J. 2005. Accuracy of coalescent likelihood estimates: do we need more sites, more sequences, or more loci? Molecular Biology and Evolution. 23, 691-700.

Ferguson, N., Cummings, D., Fraser, C., et al. 2006. Strategies for mitigating an influenza pandemic. Nature. 442, 448-452.

Flint, P.L., Ozaki, K., Pearce, J.M., Guzzetti, B., Higuchi, H., Fleskes, J.P., Shimada, T., Derksen, D.V. 2009. Breeding-season sympatry facilitates genetic exchange among allopatric wintering populations of northern pintails in Japan and California. The Condor. 111, 591-98.

Gill, J. S., Webby, R., Gilchrist, M. J. R., \& Gray, G. C. 2006. Avian influenza among waterfowl hunters and wildlife professionals. Emerging Infectious Diseases. 12, 1284-1286.

Gilsdorf, A., Boxall, N., Gasimov, V., Agayev, I., Mammadzade, F., Ursu, P., ... Ganter, B. 2006. Two clusters of human infection with influenza A/H5N1 virus in the Republic of Azerbaijan, February-March 2006. Euro Surveillance. 11, 122-126.

Goudie, R.I., Robertson, G.J., Reed, A. 2020. Common Eider (Somateria mollissima), version 1.0. In Birds of the World (S. M. Billerman, Editor). Cornell Lab of Ornithology, Ithaca, NY, USA.

Grabherr, M.G., Haas, B.J., Yassour, M., Levin, J.Z., Thompson, D.A., Amit, I., ... Regev, A. 2011. Full-length transcriptome assembly from RNA-Seq data without a reference genome. Nature Biotechnology. 29, 644-652.

Gutenkunst, R.N., Hernandez, R.D., Williamson, S.H., Bustamante, C.D. 2009. Inferring the joint demographic history of multiple populations from multidimensional SNP frequency data. PLOS Genetics. 5, e1000695.

Hines, B. 1963. Ducks at a distance: a waterfowl identification guide. U.S. Department of the Interior, Fish and Wildlife Service.

Hinshaw, V.S., Webster, R.G., Turner, B. 1980. The perpetuation of orthomyxoviruses and paramyxoviruses in Canadian waterfowl. Canadian Journal of Microbiology. 26, 622629.

Horimoto, T., Kawaoka, Y. 2001. Pandemic threat posed by avian influenza A viruses. Clinical Microbiology Reviews. 14, 129-149.

Humphries, E.M., Winker, K. 2011. Discord reigns among nuclear, mitochondrial and phenotypic estimates of divergence in nine lineages of trans-Beringian birds: discord among divergence estimates. Molecular Ecology. 20, 573-583

Johnson, K. 1995. Green-winged Teal (Anas crecca). The Birds of North America, No. 193, Ithaca, NY: Cornell Lab of Ornithology.

Kessel, B., Rocque, D.A., Barclay, J.S. 2020. Greater Scaup (Aythya marila), version 1.0. In Birds of the World (S. M. Billerman, Editor). Cornell Lab of Ornithology, Ithaca, NY, USA. 
Kilpatrick, A.M., Chmura, A.A., Gibbons, D.W., Fleischer, R.C., Marra, P.P., Daszak, P. 2006. Predicting the global spread of H5N1 avian influenza. Proceedings of the National Academy of Sciences. 103, 19368-19373.

Li, H., 2013. Aligning sequence reads, clone sequences and assembly contigs with BWA-MEM. arXiv:1303.3997v1.

Li, H., Durbin, R. 2009. Fast and accurate short read alignment with Burrows-Wheeler transform. Bioinformatics. 25, 1754-1760.

Li, H., Handsaker, B., Wysoker, A., Fennell, T., Ruan, J., Homer, N., .. 1000 Genome Project Data Processing Subgroup. 2009. The sequence alignment/map format and SAMtools. Bioinformatics. 25, 2078-2079

McKenna, A., Hanna, M., Banks, E., Sivachenko, A., Cibulskis, K., Kernytsky, A., ... DePristo, M. A. 2010. The Genome Analysis Toolkit: a mapreduce framework for analyzing nextgeneration DNA sequencing data. Genome Research. 20, 1297-1303.

McLaughlin, J.F., Faircloth, B.C., Glenn, T.C., Winker, K. 2020. Divergence, gene flow, and speciation in eight lineages of trans-Beringian birds. Molecular Ecology 29, 3526-3542.

McLaughlin, J.F., Winker, K. 2020. An empirical examination of sample size effects on population demographic estimates in birds using single nucleotide polymorphism (SNP) data. PeerJ. 8, e9939.

Mini, A.E., Harrington, H.E.R., Dugger, D.B., Mowbray, T.B. 2014. American Wigeon (Mareca americana). The Birds of North America, No. 401, Ithaca, NY: Cornell Lab of Ornithology.

National Geographic Society. 1999. Field Guide to the Birds of North America. 2nd Edition.

Naves, L.C. Keating J.M. 2020. Alaska subsistence harvest of birds and eggs, 2018, Alaska Migratory Bird Co-Management Council. Alaska Department of Fish and Game Division of Subsistence Technical Paper No. 464, Anchorage.

Naves, L.C., Keating J.M. 2018. Alaska subsistence harvest of birds and eggs, 2017, Alaska Migratory Bird Co-Management Council. Alaska Department of Fish and Game Division of Subsistence Technical Paper No. 443, Anchorage.

Naves, L.C., Otis D. 2017. Alaska subsistence harvest of birds and eggs, 2016, Alaska Migratory Bird Co-Management Council. Alaska Department of Fish and Game Division of Subsistence Technical Paper No. 434, Anchorage.

Nazareno, A.G., Bemmels, J.B., Dick, C.W., Lohmann, L.G., 2017. Minimum sample sizes for population genomics: an empirical study from an Amazonian plant species. Molecular Ecology Resources. 17, 1136-1147.

Pearce, J.M., Ramey, A.M., Flint, P.L., Koehler, A.V., Fleskes, J.P., Franson, J.C., Hall, J.S., Derksen, D.V. and Ip, H.S. 2009. Avian influenza at both ends of a migratory flyway: characterizing viral genomic diversity to optimize surveillance plans for North America. Evolutionary Applications. 2, 457-468.

Peters, J.L., McCracken, K.G., Pruett, C.L., Rohwer, S., Drovetski, S.V., Zhuravlev, Y.N., Kulikova, I., Gibson, D.D., Winker K. 2012. A parapatric propensity for breeding precludes the completion of speciation in common teal (Anas crecca, sensu lato). Molecular Ecology. 21, 4563-4577.

Picard toolkit. 2019. Broad Institute. http://broadinstitute.github.io/picard/ QIAGEN®. 2006. DNeasy Blood \& Tissue Handbook. 62. 
Ramey A,M., Reeves, A.B., Sonsthagen, S.A., TeSlaa, J.L., Nashold, S., Donnelly, T., Casler, B., Hall, J.S. 2015. Dispersal of H9N2 influenza A viruses between East Asia and North America by wild birds. Virology. 482, 79-83.

Ramey, A.M., Pearce, J.M., Flint, P.L., Ip, H.S., Derksen, D.V., Franson, J.C., Petrula, M.J., Scotton, B.D., Sowl, K.M., Wege, M.L., Trust, K.A. 2010. Intercontinental reassortment and genomic variation of low pathogenic avian influenza viruses isolated from northern pintails (Anas acuta) in Alaska: examining the evidence through space and time. Virology. 401, 179-189.

Ramey, A.M., Reeves, A.B., Donnelly, T., Poulson, R.L., Stallknecht, D.E. 2018. Introduction of Eurasian-origin influenza A (H8N4) virus into North America by migratory birds.

Emerging Infectious Diseases. 24, 1950-1952.

Rappole, J.H., Hubálek, Z. 2006. Birds and influenza H5N1 virus movement to and within North America. Emerging Infectious Diseases. 12, 1486-1492.

Reeves, A.B., Hall, J.S., Poulson, R.L., Donnelly, T., Stallknecht, D.E. Ramey, A.M. 2018. Influenza A virus recovery, diversity, and intercontinental exchange: a multi-year assessment of wild bird sampling at Izembek National Wildlife Refuge, Alaska. PLOS ONE. 13, e0195327.

Reeves, A.B., Pearce, J.M., Ramey, A.M., Ely, C.R., Schmutz, J.A., Flint, P.L., Derksen, D.V., Ip, H.S., Trust, K.A. 2013. Genomic analysis of avian influenza viruses from waterfowl in western Alaska, USA. Journal of Wildlife Diseases. 49, 600-610.

Rice, M., Haukos, D., Dubovsky, J., Runge, M. 2010. Continental survival and recovery rates of northern pintails using band-recovery data. The Journal of Wildlife Management. 74, $778-787$

Robertson, G.J., Savard, J.L. 2002. Long-tailed Duck (Clangula hyemalis). The Birds of North America, No. 650, Ithaca, NY: Cornell Lab of Ornithology.

Rocque, D.A. 1997. Population ecology and modeling of greater scaup. Thesis, University of Connecticut, Storrs, USA.

Roman, J. 2003. Whales before whaling in the North Atlantic. Science. 301, 508-510.

Sæther, B.E., Lande, R., Engen, S., Weimerskirch, H., Lillegård, M., Altwegg, R., ... Visser, M. E. 2005. Generation time and temporal scaling of bird population dynamics. Nature. 436, 99-102.

Sellwood, C., Asgari-Jirhandeh, N., Salimee, S. 2007. Bird flu: if or when? planning for the next pandemic. Postgraduate Medical Journal. 83, 445-450.

Siembieda, J., Johnson, C. K., Boyce, W. M., Sandrock, C., \& Cardona, C. 2008. Risk for avian influenza virus exposure at human-wildlife interface. Emerging Infectious Diseases. 14, $1151-1153$

Sonsthagen, S.A., Talbot, S.L., Scribner, K.T., McCracken, K.G. 2011. Multilocus phylogeography and population structure of common eiders breeding in North America and Scandinavia. Journal of Biogeography. 38, 1368-1380.

Sonsthagen, S.A., Wilson, R.E., Lavretsky, P., Talbot, S.L. 2019. Coast to coast: high genomic connectivity in North American scoters. Ecology and Evolution. 9, 7246-7261.

Talbot, S.L., Sonsthagen, S.A., Pearce, J.M., Scribner, K.T. 2015. Phylogenetics, phylogeography and population genetics of North American sea ducks (tribe: Mergini). Ecology and Conservation of North American Sea Ducks; Studies in Avian Biology. 46, 29-62. 
U.S. Fish and Wildlife Service (USFWS). 2019. Waterfowl population status, 2019. U.S.

Department of the Interior, Washington, D.C. USA.

Van Gils, J., Wiersma, P., Kirwan, G.M., Sharpe, C.J. 2020. Common Snipe (Gallinago gallinago), version 1.0. In Birds of the World (J. del Hoyo, A. Elliott, J. Sargatal, D. A. Christie, and E. de Juana, Editors). Cornell Lab of Ornithology, Ithaca, NY, USA.

Webster, R.G., Bean, W.J., Gorman, O.T., Chambers, T.M., Kawaoka, Y. 1992. Evolution and ecology of influenza A viruses. Microbiological Reviews. 56(1), 152-179.

Wetlands International. 2021. Waterbird population estimates. Retrieved from wpe.wetlands.org on Sunday 30 May 2021

Winker, K., Gibson, D.D. 2010. The Asia-to-America influx of avian influenza wild bird hosts is large. Avian Diseases. 54(1), 477-482.

Winker, K., Glenn, T.C., Faircloth, B.C. 2018. Ultraconserved elements (UCEs) illuminate the population genomics of a recent, high-latitude avian speciation event. PeerJ. 6.

Winker, K., Glenn, T.C., Withrow, J., Sealy, S.G., Faircloth, B.C. 2019. Speciation despite gene flow in two owls (Aegolius ssp.): evidence from 2,517 ultraconserved element loci. The Auk. 136.

Winker, K., McCracken, K.G., Gibson, D.D., Pruett, C.L., Meier, R., Huettmann, F., Wege, M., Kulikova, I.V., Zhuravlev, Y.N., Perdue, M.L., Spackman, E., Suarez, D.L., Swayne, D.E. 2007. Movements of birds and avian influenza from Asia into Alaska. Emerging Infectious Diseases. 13(4), 547-552.

Yamamoto, Y., Nakamura, K., Yamada, M., \& Mase, M. 2010. Persistence of avian influenza virus (H5N1) in feathers detached from bodies of infected domestic ducks. Applied and Environmental Microbiology. 76, 5496-5499. 


\subsection{Appendix: Supplementary Information}

Table S1. Specimen information of individuals used in this study. Note that UAM = University of Alaska Museum; UWBM = University of Washington Burke Museum. All SRA reads available under project PRJNA741809 and project PRJNA741698.

*Individuals from McLaughlin et al. (2020). All SRA reads available under project PRJNA393740.

**Individuals considered to be of Eurasian origin (if not classified at the subspecies or species level).

***Individuals considered to be of North American origin (if not classified at the subspecies or species level).

\begin{tabular}{|c|c|c|c|c|}
\hline Taxon & Locality & $\begin{array}{l}\text { Tissue } \\
\text { Number }\end{array}$ & $\begin{array}{c}\text { Catalogue } \\
\text { Number }\end{array}$ & $\begin{array}{c}\text { Sequence Read } \\
\text { Archive }\end{array}$ \\
\hline \multicolumn{5}{|c|}{ Green-winged Teal (Anas crecca crecca and $A$. c. carolinensis)* } \\
\hline Anas crecca crecca & $\begin{array}{l}\text { Alaska: Aleutian Islands, } \\
\text { Shemya Island }\end{array}$ & UAM9191 & DDG1732 & SRX2999024 \\
\hline Anas crecca crecca & $\begin{array}{l}\text { Alaska: Aleutian Islands, } \\
\text { Shemya Island }\end{array}$ & UAM9255 & DDG1704 & SRX2998981 \\
\hline Anas crecca crecca & $\begin{array}{l}\text { Alaska: Aleutian Islands, } \\
\text { Shemya Island }\end{array}$ & UAM14666 & DDG1884 & SRX2998973 \\
\hline Anas crecca crecca & $\begin{array}{l}\text { Alaska: Aleutian Islands, } \\
\text { Shemya Island }\end{array}$ & UAM14100 & DDG1885 & SRX2998978 \\
\hline Anas crecca crecca & $\begin{array}{l}\text { Alaska: Aleutian Islands, } \\
\text { Shemya Island }\end{array}$ & UAM11334 & KGM021 & SRX2998980 \\
\hline Anas crecca crecca & $\begin{array}{l}\text { Alaska: Aleutian Islands, } \\
\text { Shemya Island }\end{array}$ & UAM11335 & KGM020 & SRX2998979 \\
\hline Anas crecca crecca & $\begin{array}{l}\text { Russia: Yakutia, Indigirka } \\
\text { River }\end{array}$ & UAM22853 & KSW4951 & SRX2998972 \\
\hline Anas crecca carolinensis & $\begin{array}{l}\text { Alaska: Alaska Peninsula, } \\
\text { Izembek NWR }\end{array}$ & UAM14961 & KGM335 & SRX2998946 \\
\hline Anas crecca carolinensis & $\begin{array}{l}\text { Alaska: Alaska Peninsula, } \\
\text { Izembek NWR }\end{array}$ & UAM24497 & JMM448 & SRX2998977 \\
\hline Anas crecca carolinensis & Alaska: Fairbanks & UAM11920 & KSW3040 & SRX2998949 \\
\hline
\end{tabular}


Table S1, continued.

\begin{tabular}{|c|c|c|c|c|}
\hline Anas crecca carolinensis & $\begin{array}{l}\text { Alaska: Alaska Peninsula, Cold } \\
\text { Bay }\end{array}$ & UAM20635 & KSW4530 & SRX2998947 \\
\hline Anas crecca carolinensis & $\begin{array}{l}\text { Alaska: Interior, Eielson Air } \\
\text { Force Base }\end{array}$ & UAM11251 & UAMX203 & SRX2998948 \\
\hline Anas crecca carolinensis & $\begin{array}{l}\text { Alaska: Aleutian Islands, } \\
\text { Chirikof Island }\end{array}$ & UAM28444 & UAMX5069 & SRX2998975 \\
\hline \multicolumn{5}{|c|}{ Long-tailed Duck (Clangula hyemalis)* } \\
\hline Clangula hyemalis $* *$ & $\begin{array}{l}\text { Russia: Chukotka Autonomous } \\
\text { Okrug }\end{array}$ & UWBM43893 & CSW4426 & SRX2998961 \\
\hline Clangula hyemalis** & $\begin{array}{l}\text { Russia: Chukotka Autonomous } \\
\text { Okrug }\end{array}$ & UWBM43894 & CSW4427 & SRX2998960 \\
\hline Clangula hyemalis** & $\begin{array}{l}\text { Russia: Chukotka Autonomous } \\
\text { Okrug }\end{array}$ & UWBM43895 & CSW4428 & SRX2998917 \\
\hline Clangula hyemalis** & $\begin{array}{l}\text { Russia: Chukotka Autonomous } \\
\text { Okrug }\end{array}$ & UWBM43917 & CSW4452 & SRX2998966 \\
\hline Clangula hyemalis** & $\begin{array}{l}\text { Russia: Chukotka Autonomous } \\
\text { Okrug }\end{array}$ & UWBM43918 & CSW4453 & SRX2998940 \\
\hline Clangula hyemalis** & $\begin{array}{l}\text { Russia: Chukotka Autonomous } \\
\text { Okrug }\end{array}$ & UWBM43919 & CSW4454 & SRX2998941 \\
\hline Clangula hyemalis ** & $\begin{array}{l}\text { Russia: Chukotka Autonomous } \\
\text { Okrug }\end{array}$ & UWBM43970 & CSW4514 & SRX2998942 \\
\hline Clangula hyemalis $* * *$ & Alaska: Utqiaġvik & UAM13154 & DAR149 & SRX2999003 \\
\hline Clangula hyemalis $* * *$ & $\begin{array}{l}\text { Alaska: North Slope, Dalton } \\
\text { Hwy. }\end{array}$ & UAM21883 & REW583 & SRX2998959 \\
\hline Clangula hyemalis $* * *$ & $\begin{array}{l}\text { Alaska: North Slope, Dalton } \\
\text { Hwy. }\end{array}$ & UAM21931 & REW532 & SRX2998958 \\
\hline Clangula hyemalis $* * *$ & $\begin{array}{l}\text { Alaska: North Slope, Dalton } \\
\text { Hwy. }\end{array}$ & UAM28184 & REW619 & SRX2998957 \\
\hline Clangula hyemalis $* * *$ & $\begin{array}{l}\text { Alaska: North Slope, Dalton } \\
\text { Hwy. }\end{array}$ & UAM29027 & REW618 & SRX2998956 \\
\hline
\end{tabular}


Table S1, continued.

$\begin{array}{llll}\text { Clangula hyemalis } * * * & \text { Alaska: North Slope, Dalton } & \text { UAM29029 } & \text { REW620 }\end{array}$

\begin{tabular}{|c|c|c|c|c|}
\hline \multicolumn{5}{|c|}{ Eurasian-American Wigeon (Mareca penelope - M. americana)* } \\
\hline Mareca penelope & $\begin{array}{l}\text { Alaska: Aleutian Islands, } \\
\text { Buldir Island }\end{array}$ & UAM8758 & DDG1663 & SRX2998927 \\
\hline Mareca penelope & $\begin{array}{l}\text { Alaska: Aleutian Islands, } \\
\text { Shemya Island }\end{array}$ & UAM9359 & DDG1703 & SRX2998926 \\
\hline Mareca penelope & $\begin{array}{l}\text { Alaska: Aleutian Islands, } \\
\text { Shemya Island }\end{array}$ & UAM10008 & DDG1716 & SRX2998954 \\
\hline Mareca penelope & $\begin{array}{l}\text { Alaska: Aleutian Islands, } \\
\text { Shemya Island }\end{array}$ & UAM11803 & DDG1768 & SRX2998955 \\
\hline Mareca penelope & $\begin{array}{l}\text { Alaska: Aleutian Islands, } \\
\text { Shemya Island }\end{array}$ & UAM24301 & UAMX4959 & SRX2998952 \\
\hline Mareca penelope & $\begin{array}{l}\text { Alaska: Aleutian Islands, Attu } \\
\text { Island }\end{array}$ & UAM24455 & MJL037 & SRX2998953 \\
\hline Mareca penelope & $\begin{array}{l}\text { Alaska: Aleutian Islands, } \\
\text { Shemya Island }\end{array}$ & UAM24550 & UAMX5044 & SRX2998950 \\
\hline Mareca penelope & $\begin{array}{l}\text { Alaska: Aleutian Islands, } \\
\text { Shemya Island }\end{array}$ & UAM27749 & JJW968 & SRX2998951 \\
\hline Mareca americana & Alaska: Fairbanks & UAM11908 & KSW3028 & SRX2998933 \\
\hline Mareca americana & Alaska: Fairbanks & UAM11909 & KSW3029 & SRX2998932 \\
\hline Mareca americana & Alaska: Fairbanks & UAM11916 & KSW3036 & SRX2998935 \\
\hline Mareca americana & Alaska: Fairbanks & UAM11919 & KSW3039 & SRX2998934 \\
\hline Mareca americana & Alaska: Fairbanks & UAM13141 & UAMX1468 & SRX2998929 \\
\hline Mareca americana & $\begin{array}{l}\text { Alaska: Interior, Eielson Air } \\
\text { Force Base }\end{array}$ & UAM26061 & JJW383 & SRX2998928 \\
\hline Mareca americana & $\begin{array}{l}\text { Alaska: Kodiak Island, } \\
\text { Monashka Bay }\end{array}$ & UAM28087 & JJW976 & SRX2998931 \\
\hline Mareca americana & $\begin{array}{l}\text { Alaska: Kodiak Island, } \\
\text { Deadman Bay }\end{array}$ & UAM28088 & JJW948 & SRX2998930 \\
\hline
\end{tabular}


Table S1, continued.

\begin{tabular}{|c|c|c|c|c|}
\hline \multicolumn{5}{|c|}{ Northern Pintail (Anas acuta) } \\
\hline Anas acuta** & $\begin{array}{l}\text { Russia: Chukotka Autonomous } \\
\text { Okrug }\end{array}$ & UWBM44114 & DAB055 & SRR14930358 \\
\hline Anas acuta** & $\begin{array}{l}\text { Alaska: Aleutian Islands, } \\
\text { Shemya Island }\end{array}$ & UAM22595 & DDG2122 & SRR14930357 \\
\hline Anas acuta*** & $\begin{array}{l}\text { Alaska: North Slope, } \\
\text { Deadhorse }\end{array}$ & UAM23468 & KGM895 & SRR14930335 \\
\hline Anas acuta** & $\begin{array}{l}\text { Russia: Yakutia, Indigirka } \\
\text { River }\end{array}$ & UAM28156 & KSW5 107 & SRR14930324 \\
\hline Anas acuta** & $\begin{array}{l}\text { Russia: Kamchatka, Sea of } \\
\text { Okhotsk }\end{array}$ & UAM30400 & KSW5391 & SRR 14930314 \\
\hline Anas acuta*** & $\begin{array}{l}\text { Alaska: North Slope, Dalton } \\
\text { Hwy. }\end{array}$ & UAM29039 & REW548 & SRR 14930313 \\
\hline Anas acuta*** & $\begin{array}{l}\text { Alaska: North Slope, Dalton } \\
\text { Hwy. }\end{array}$ & UAM22113 & REW601 & SRR14930312 \\
\hline Anas acuta*** & $\begin{array}{l}\text { Alaska: Interior, Eielson Air } \\
\text { Force Base }\end{array}$ & UAM31335 & UAMX5487 & SRR14930311 \\
\hline Anas acuta $* * *$ & $\begin{array}{l}\text { Alaska: Interior, Eielson Air } \\
\text { Force Base }\end{array}$ & UAM31205 & JJW 1897 & SRR14930346 \\
\hline Anas acuta** & $\begin{array}{l}\text { Russia: Yakutia, Indigirka } \\
\text { River }\end{array}$ & UAM28167 & KSW5 120 & SRR14930315 \\
\hline \multicolumn{5}{|c|}{ Mallard (Anas platyrynchos) } \\
\hline Anas platyrhynchos*** & Alaska: Interior, Chena River & UAM11193 & KGM007 & SRR15011471 \\
\hline Anas platyrhynchos *** & $\begin{array}{l}\text { Alaska: Interior, Eielson Air } \\
\text { Force Base }\end{array}$ & UAM30286 & JJW1602 & SRR15011470 \\
\hline Anas platyrhynchos ** & $\begin{array}{l}\text { Alaska: Aleutian Islands, } \\
\text { Shemya Island }\end{array}$ & UAM11328 & DDG1776 & SRR15011469 \\
\hline Anas platyrhynchos** & $\begin{array}{l}\text { Russia: Khabarovsk Krai, } \\
\text { Nizhnetambovskoye }\end{array}$ & UWBM47068 & CSW4828 & SRR14930356 \\
\hline
\end{tabular}


Table S1, continued.

\begin{tabular}{|c|c|c|c|c|}
\hline Anas platyrhynchos *** & $\begin{array}{l}\text { Alaska: Kodiak Island, } \\
\text { Deadman Bay }\end{array}$ & UAM28089 & JJW943 & SRR14930349 \\
\hline Anas platyrhynchos *** & $\begin{array}{l}\text { Alaska: Kodiak Island, } \\
\text { Deadman Bay }\end{array}$ & UAM28074 & JJW944 & SRR14930348 \\
\hline Anas platyrhynchos *** & $\begin{array}{l}\text { Alaska: Kodiak Island, } \\
\text { Womens Bay }\end{array}$ & UAM29647 & JJW 1397 & SRR14930355 \\
\hline Anas platyrhynchos*** & $\begin{array}{l}\text { Alaska: Interior, Eielson Air } \\
\text { Force Base }\end{array}$ & UAM30290 & JJW 1592 & SRR14930354 \\
\hline Anas platyrhynchos ** & $\begin{array}{l}\text { Russia: Magadan Oblast, } \\
\text { Balagannoye }\end{array}$ & UWBM44374 & JMB1220 & SRR14930353 \\
\hline Anas platyrhynchos ** & $\begin{array}{l}\text { Russia: Kamchatka, Sea of } \\
\text { Okhotsk }\end{array}$ & UAM30399 & KSW5390 & SRR14930352 \\
\hline Anas platyrhynchos *** & $\begin{array}{l}\text { Alaska: Interior, Eielson Air } \\
\text { Force Base }\end{array}$ & UAM31321 & UAMX5540 & SRR 14930350 \\
\hline Anas platyrhynchos** & $\begin{array}{l}\text { Russia: Khabarovsk Krai, } \\
\text { Nizhnetambovskoye }\end{array}$ & UWBM47160 & SAR6383 & SRR14930351 \\
\hline \multicolumn{5}{|c|}{ Greater Scaup (Aythya marila) } \\
\hline Aythya marila** & $\begin{array}{l}\text { Russia: Kamchatka, Sea of } \\
\text { Okhotsk }\end{array}$ & UAM30393 & KSW5396 & SRR 14930340 \\
\hline Aythya marila*** & $\begin{array}{l}\text { Alaska: Aleutian Islands, Little } \\
\text { Kiska Island }\end{array}$ & UAM28068 & JJW325 & SRR 14930345 \\
\hline Aythya marila*** & $\begin{array}{l}\text { Alaska: Aleutian Islands, Little } \\
\text { Kiska Island }\end{array}$ & UAM28067 & JJW324 & SRR14930347 \\
\hline Aythya marila** & $\begin{array}{l}\text { Russia: Kamchatka, Sea of } \\
\text { Okhotsk }\end{array}$ & UAM30395 & KSW5385 & SRR14930344 \\
\hline Aythya marila** & $\begin{array}{l}\text { Russia: Kamchatka, Sea of } \\
\text { Okhotsk }\end{array}$ & UAM30394 & KSW5393 & SRR14930343 \\
\hline Aythya marila** & $\begin{array}{l}\text { Russia: Kamchatka, Sea of } \\
\text { Okhotsk }\end{array}$ & UAM30392 & KSW5394 & SRR14930342 \\
\hline Aythya marila** & $\begin{array}{l}\text { Russia: Kamchatka, Sea of } \\
\text { Okhotsk }\end{array}$ & UAM30396 & KSW5395 & SRR14930341 \\
\hline
\end{tabular}


Table S1, continued.

\begin{tabular}{|c|c|c|c|c|}
\hline Aythya marila*** & $\begin{array}{l}\text { Alaska: North Slope, Dalton } \\
\text { Hwy. }\end{array}$ & UAM35653 & REW611 & SRR14930339 \\
\hline Aythya marila*** & Alaska: Chirikof Island & UAM30915 & UAMX5076 & SRR14930338 \\
\hline Aythya marila*** & Alaska: Chirikof Island & UAM29987 & UAMX5077 & SRR14930337 \\
\hline \multicolumn{5}{|c|}{ Common Eider (Somateria mollissima) } \\
\hline Somateria mollissima** & $\begin{array}{l}\text { Alaska: Aleutian Islands, Attu } \\
\text { Island }\end{array}$ & UAM36746 & KGM912 & SRR14930328 \\
\hline $\begin{array}{l}\text { Somateria } \\
\text { mollissima*** }\end{array}$ & $\begin{array}{l}\text { Alaska: Kodiak Island, } \\
\text { Womens Bay }\end{array}$ & UAM34700 & JJW2273 & SRR14930333 \\
\hline Somateria mollissima** & $\begin{array}{l}\text { Alaska: Aleutian Islands, Attu } \\
\text { Island }\end{array}$ & UAM13336 & DAR157 & SRR 14930336 \\
\hline Somateria mollissima** & $\begin{array}{l}\text { Alaska: Aleutian Islands, Attu } \\
\text { Island }\end{array}$ & UAM20085 & DDG1939 & SRR14930334 \\
\hline $\begin{array}{l}\text { Somateria } \\
\text { mollissima*** }\end{array}$ & $\begin{array}{l}\text { Alaska: Kodiak Island, } \\
\text { Womens Bay }\end{array}$ & UAM34628 & JJW2274 & SRR 14930332 \\
\hline $\begin{array}{l}\text { Somateria } \\
\text { mollissima*** }\end{array}$ & $\begin{array}{l}\text { Alaska: Kodiak Island, Shuyak } \\
\text { Island }\end{array}$ & UAM35411 & JJW2452 & SRR14930331 \\
\hline $\begin{array}{l}\text { Somateria } \\
\text { mollissima*** }\end{array}$ & $\begin{array}{l}\text { Alaska: Beaufort Sea, North } \\
\text { Star Island }\end{array}$ & UAM37604 & JJW2952 & SRR 14930330 \\
\hline Somateria mollissima** & $\begin{array}{l}\text { Alaska: Aleutian Islands, Attu } \\
\text { Island }\end{array}$ & UAM36436 & KGM845 & SRR14930329 \\
\hline Somateria mollissima $* *$ & $\begin{array}{l}\text { Alaska: Aleutian Islands, Attu } \\
\text { Island }\end{array}$ & UAM13721 & UAMX1708 & SRR 14930327 \\
\hline $\begin{array}{l}\text { Somateria } \\
\text { mollissima }^{* * *}\end{array}$ & Alaska: Utqiag்vik & UAM9440 & UAMX378 & SRR14930326 \\
\hline \multicolumn{5}{|c|}{ Common-Wilson's Snipe (Gallinago gallinago - G. delicata) } \\
\hline Gallinago gallinago & $\begin{array}{l}\text { Alaska: Aleutian Islands, Attu } \\
\text { Island }\end{array}$ & UAM21848 & CLP713 & SRR14930320 \\
\hline Gallinago gallinago & $\begin{array}{l}\text { Alaska: Aleutian Islands, Adak } \\
\text { Island }\end{array}$ & UAM8228 & DDG1650 & SRR14930319 \\
\hline
\end{tabular}


Table S1, continued.

\begin{tabular}{llccc} 
Gallinago gallinago & $\begin{array}{l}\text { Alaska: Aleutian Islands, Attu } \\
\text { Island }\end{array}$ & UAM26799 & JJW158 & SRR14930318 \\
Gallinago gallinago & $\begin{array}{l}\text { Russia: Yakutia, Indigirka } \\
\text { River }\end{array}$ & UAM24695 & KSW5126 & SRR14930317 \\
Gallinago gallinago & $\begin{array}{l}\text { Russia: Yakutia, Indigirka } \\
\text { River } \\
\text { Alaska: Aleutian Islands, }\end{array}$ & UAM28175 & KSW5134 & SRR14930316 \\
Gallinago delicata & $\begin{array}{l}\text { Unalaska Island } \\
\text { Alaska: Aleutian Islands, }\end{array}$ & UAM19231 & DDG2021 & SRR14930323 \\
Gallinago delicata & $\begin{array}{l}\text { Unimak Island } \\
\text { Alaska: Goodnews Bay } \\
\text { Alaska: Aleutian Islands, Adak }\end{array}$ & UAM20505 & DDG1945 & SRR14930325 \\
Gallinago delicata & Usland & DDG2035 & SRR14930322 \\
\hline
\end{tabular}


Table S2. Values used to translate $\delta a \delta i$ output into biological estimates of demographic parameters. The equation for generation time $G=\alpha-[s /(1-s)]$ was obtained from Saether et al. (2005). Substitutions = mutations/site/year. To calculate substitution rates we used fossil-calibrated nodes from Claramunt \& Cracraft (2015). In ducks, we used a node within Anseriformes (Anser cygnoides; GenBank accession: GCA_000971095.1) with a date of 28.13 Ma. For shorebirds, we used a node within the Charadriiformes (Charadrius vociferus; GenBank accession: GCA_000708025.2) with a date of 29.78 Ma. The biological estimate for ancestral population size $\left(N_{r e f}\right)$, is derived from the output of $\Theta$ from $\delta a \delta i$, where $\Theta=4 * N_{\text {ref }} *$ substitution rate. * Results from McLaughlin et al. (2020)

\begin{tabular}{|c|c|c|c|c|c|}
\hline Vector Species & $\begin{array}{c}\text { Age of } \\
\text { Maturity } \\
(\alpha, \text { years })\end{array}$ & $\begin{array}{l}\text { Annual Adult } \\
\text { Survival } \\
\text { (s) }\end{array}$ & $\begin{array}{l}\text { Generation } \\
\text { Time } \\
\text { (G) }\end{array}$ & $\begin{array}{l}\text { Substitution } \\
\text { Rate }\end{array}$ & References \\
\hline $\begin{array}{l}\text { Green-winged Teal* } \\
\text { (Anas crecca crecca-A.c. } \\
\text { carolinensis) }\end{array}$ & 1 & 0.60 & 2.5 & $1.224 \times 10^{-9}$ & Johnson (1995) \\
\hline $\begin{array}{l}\text { Long-tailed Duck* } \\
\text { (Clangula hyemalis) }\end{array}$ & 2 & 0.75 & 5 & $2.270 \times 10^{-9}$ & $\begin{array}{l}\text { Robertson \& Savard, } \\
(2002)\end{array}$ \\
\hline $\begin{array}{l}\text { Eurasian-American Wigeon* } \\
\text { (Mareca penelope }-M \text {. } \\
\text { americana) }\end{array}$ & 1 & 0.64 & 2.74 & $1.084 \times 10^{-9}$ & $\begin{array}{l}\text { Arnold \& Clark, (1996) } \\
\text { Mini et al., (2014) }\end{array}$ \\
\hline $\begin{array}{l}\text { Northern Pintail } \\
(\text { Anas acuta) }\end{array}$ & 1 & 0.69 & 3.25 & $3.83 \times 10^{-10}$ & $\begin{array}{l}\text { Bellrose (1976) } \\
\text { Rice et al. (2010) }\end{array}$ \\
\hline $\begin{array}{l}\text { Mallard } \\
\text { (Anas platyrhynchos) }\end{array}$ & 1 & 0.61 & 2.55 & $3.41 \times 10^{-10}$ & Drilling et al. (2020) \\
\hline $\begin{array}{l}\text { Greater Scaup } \\
(\text { Aythya marila) }\end{array}$ & 1 & 0.75 & 4 & $3.23 \times 10^{-9}$ & $\begin{array}{l}\text { Rocque (1997) } \\
\text { Kessel et al. (2020) }\end{array}$ \\
\hline $\begin{array}{l}\text { Common Eider } \\
\text { (Somateria mollissima) }\end{array}$ & 3 & 0.86 & 9.23 & $3.14 \times 10^{-10}$ & Goudie et al., (2020) \\
\hline
\end{tabular}


Table S2, continued.

\section{Common- Wilson's Snipe}

(Gallinago gallinago - G .

1.99

$9.45 \times 10^{-10}$

Van Gils et al. (2020) delicata) 
Table S3. AIC and negative log-likelihood values (in parentheses) for each pairwise comparison for the eight demographic models tested ("migration" = gene flow; S1A-H refer to Supplementary Fig 1 model depictions). . When selecting best-fit models, some models had a $\triangle \mathrm{AIC}$ of $<10$, which indicates models that are not statistically separable in their likelihood of explaining the data. Calculating $\triangle \mathrm{AIC}$ causes the best model to have $\triangle \mathrm{AIC}=0$, while the rest of the models have positive values (Burnham $\&$ Anderson, 2004). Best-fit models with a weighted AIC of 1 are in bold, while runner-up models $(\triangle \mathrm{AIC}<10)$ are italicized. Table S5 for $\Delta \mathrm{AIC}$ values and weighted AIC values. *Results from McLaughlin et al. (2020). Note that the "n.a." values indicate a $\Delta$ AIC of $<10$. These models were unable to find a stable configuration, and thus could not be run to completion (see McLaughlin et al. 2020, Table 3).

\begin{tabular}{|c|c|c|c|c|c|c|c|c|}
\hline $\begin{array}{l}\text { Pairwise comparison } \\
(\mathrm{nu} 1 \text { - nu2) }\end{array}$ & $\begin{array}{l}\text { Neutral } \\
\text { (Fig. S1A) }\end{array}$ & $\begin{array}{l}\text { split with no } \\
\text { migration } \\
\text { (Fig. S1B) }\end{array}$ & $\begin{array}{l}\text { split with } \\
\text { migration, } 1 \\
\text { migration } \\
\text { parameter } \\
\text { (Fig. S1C) }\end{array}$ & $\begin{array}{c}\text { split with } \\
\text { bidirectional } \\
\text { migration, } 2 \\
\text { migration } \\
\text { parameters } \\
\text { (Fig. S1D) }\end{array}$ & $\begin{array}{l}\text { split with } \\
\text { exponential } \\
\text { population } \\
\text { growth, no } \\
\text { migration } \\
\text { (Fig. S1E) }\end{array}$ & $\begin{array}{c}\text { split with } \\
\text { exponential } \\
\text { population } \\
\text { growth, } \\
\text { migration } \\
\text { (Fig. S1F) }\end{array}$ & $\begin{array}{l}\text { secondary } \\
\text { contact, } 1 \\
\text { migration } \\
\text { parameter } \\
\text { (Fig. S1G) }\end{array}$ & $\begin{array}{c}\text { secondary } \\
\text { contact, } 2 \\
\text { migration } \\
\text { parameters } \\
\text { (Fig. S1H) }\end{array}$ \\
\hline $\begin{array}{l}\text { Green-winged Teal* } \\
\text { (Anas crecca crecca-A.c. } \\
\text { carolinensis) }\end{array}$ & $\begin{array}{c}2,587.00 \\
(-1,291.50)\end{array}$ & n.a. & $\begin{array}{c}498.8 \\
(-245.40)\end{array}$ & $\begin{array}{c}475.46 \\
(-232.73)\end{array}$ & $\begin{array}{c}3,197.62 \\
(-1,593.81)\end{array}$ & n.a. & $\begin{array}{c}517.34 \\
(-253.67)\end{array}$ & $\begin{array}{c}474.94 \\
(-231.47)\end{array}$ \\
\hline $\begin{array}{l}\text { Long-tailed Duck* } \\
\text { (Clangula hyemalis) }\end{array}$ & $\begin{array}{c}2,480.02 \\
(-1,238.01)\end{array}$ & n.a. & $\begin{array}{c}499.74 \\
(-245.87)\end{array}$ & $\begin{array}{c}527.78 \\
(-258.89)\end{array}$ & $\begin{array}{c}5,692.16 \\
(-2,841.08)\end{array}$ & n.a. & $\begin{array}{c}442.92 \\
(-216.46)\end{array}$ & $\begin{array}{c}459.00 \\
(-223.50)\end{array}$ \\
\hline $\begin{array}{l}\text { Eurasian-American } \\
\text { Wigeon* } \\
\text { (Mareca penelope }-M \text {. } \\
\text { americana) }\end{array}$ & $\begin{array}{c}2,690.50 \\
(-1,343.25)\end{array}$ & n.a. & $\begin{array}{c}570.10 \\
(-281.05)\end{array}$ & $\begin{array}{c}605.56 \\
(-297.78)\end{array}$ & $\begin{array}{c}4,324.90 \\
(-2,157.45)\end{array}$ & $\begin{array}{l}1,869.98 \\
(-929.99)\end{array}$ & $\begin{array}{c}547.81 \\
(-268.91)\end{array}$ & $\begin{array}{c}531.36 \\
(-259.68)\end{array}$ \\
\hline $\begin{array}{l}\text { Northern Pintail } \\
(\text { Anas acuta) }\end{array}$ & $\begin{array}{c}691.21 \\
(-343.61)\end{array}$ & $\begin{array}{c}868.93 \\
(-431.46)\end{array}$ & $\begin{array}{c}231.66 \\
(-111.83)\end{array}$ & $\begin{array}{c}261.79 \\
(-125.89)\end{array}$ & $\begin{array}{l}1,124.83 \\
(-558.41)\end{array}$ & $\begin{array}{c}492.50 \\
(-241.25)\end{array}$ & $\begin{array}{c}356.07 \\
(-173.03)\end{array}$ & $\begin{array}{c}451.00 \\
(-219.50)\end{array}$ \\
\hline $\begin{array}{l}\text { Mallard } \\
\text { (Anas platyrhynchos) }\end{array}$ & $\begin{array}{c}515.75 \\
(-255.88)\end{array}$ & $\begin{array}{c}384.73 \\
(-189.36)\end{array}$ & $\begin{array}{c}187.83 \\
(-89.92)\end{array}$ & $\begin{array}{c}423.50 \\
(-206.75)\end{array}$ & $\begin{array}{c}530.56 \\
(-260.28)\end{array}$ & $\begin{array}{c}346.12 \\
(-261.98)\end{array}$ & $\begin{array}{c}284.54 \\
(-137.27)\end{array}$ & $\begin{array}{c}303.31 \\
(-145.66)\end{array}$ \\
\hline
\end{tabular}


Table S3, continued.

\begin{tabular}{l|cccccccc}
$\begin{array}{l}\text { Greater Scaup } \\
\text { (Aythya marila) }\end{array}$ & 213.92 & 250.28 & $\mathbf{1 7 1 . 1 0}$ & 180.45 & 418.04 & 226.04 & 173.10 & 174.65 \\
$\begin{array}{l}\text { Common Eider } \\
\text { (Somateria mollissima) }\end{array}$ & $(-104.96)$ & $(-122.14)$ & $\mathbf{( - 8 1 . 5 5 )}$ & $(-85.23)$ & $(-205.02)$ & $(-108.02)$ & $(-81.55)$ & $(-81.33)$ \\
$\begin{array}{l}\text { Common-Wilson's Snipe } \\
\text { (Gallinago gallinago }-G .\end{array}$ & $(-159.05)$ & $(-148.02)$ & $(-130.55)$ & $\mathbf{( - 1 2 8 . 9 6 )}$ & $(-357.53)$ & $(-174.66)$ & $(-130.54)$ & $(-128.62)$ \\
delicata) & & & & & & & & \\
& $(-1,213.99)$ & $(-359.22)$ & $(-183.50)$ & $\mathbf{( - 1 7 2 . 6 0 )}$ & $(-554.91)$ & $(-272.54)$ & $(-175.42)$ & $(-335.21)$ \\
\hline
\end{tabular}


Table S4. $\triangle \mathrm{AIC}$ and weighted AIC values (in parentheses) for each pairwise comparison for the eight demographic models tested ("migration" = gene flow). Best-fit models with a $\triangle \mathrm{AIC}$ of 0 and weighted AIC of 1 are in bold. Models that are not statistically separable from the best-fit models $(\Delta \mathrm{AIC}$ of $<10)$ are italicized. *Results from McLaughlin et al. (2020). "n.a." values indicate models that were unable to find a stable configuration and thus could not be run to completion (see McLaughlin et al. 2020, Table 3).

\begin{tabular}{|c|c|c|c|c|c|c|c|c|}
\hline $\begin{array}{l}\text { Pairwise comparison } \\
\text { (nu1 - nu2) }\end{array}$ & $\begin{array}{c}\text { Neutral } \\
\text { (Fig. S1A) }\end{array}$ & $\begin{array}{l}\text { split with no } \\
\text { migration } \\
\text { (Fig. S1B) }\end{array}$ & $\begin{array}{l}\text { split with } \\
\text { migration, } 1 \\
\text { migration } \\
\text { parameter } \\
\text { (Fig. S1C) }\end{array}$ & $\begin{array}{c}\text { split with } \\
\text { bidirectional } \\
\text { migration, } 2 \\
\text { migration } \\
\text { parameters } \\
\text { (Fig. S1D) }\end{array}$ & $\begin{array}{l}\text { split with } \\
\text { exponential } \\
\text { population } \\
\text { growth, no } \\
\text { migration } \\
\text { (Fig. S1E) }\end{array}$ & $\begin{array}{l}\text { split with } \\
\text { exponential } \\
\text { population } \\
\text { growth, } \\
\text { migration } \\
\text { (Fig. S1F) }\end{array}$ & $\begin{array}{l}\text { secondary } \\
\text { contact, } 1 \\
\text { migration } \\
\text { parameter } \\
\text { (Fig. S1G) }\end{array}$ & $\begin{array}{l}\text { secondary } \\
\text { contact, } 2 \\
\text { migration } \\
\text { parameters } \\
\text { (Fig. S1H) }\end{array}$ \\
\hline $\begin{array}{l}\text { Green-winged Teal* } \\
(\text { Anas crecca crecca-A. c. } \\
\text { carolinensis) }\end{array}$ & $\begin{array}{l}2,112.06 \\
\quad(0.00)\end{array}$ & n.a. & $\begin{array}{c}23.86 \\
\left(6.59 \times 10^{-6}\right)\end{array}$ & $\begin{array}{c}0.52 \\
(0.77)\end{array}$ & $\begin{array}{l}2,720.68 \\
(0.00)\end{array}$ & n.a. & $\begin{array}{c}42.40 \\
\left(6.21 \times 10^{-10}\right)\end{array}$ & $\begin{array}{c}0.00 \\
(1.00)\end{array}$ \\
\hline $\begin{array}{l}\text { Long-tailed Duck* } \\
\text { (Clangula hyemalis) }\end{array}$ & $\begin{array}{l}2,037.10 \\
(0.00)\end{array}$ & n.a. & $\begin{array}{c}56.82 \\
\left(4.59 \times 10^{-4}\right)\end{array}$ & $\begin{array}{c}84.86 \\
\left(3.74 \times 10^{-19}\right)\end{array}$ & $\begin{array}{l}5,247.24 \\
(0.00)\end{array}$ & n.a. & $\begin{array}{c}0.00 \\
(1.00)\end{array}$ & $\begin{array}{c}16.08 \\
\left(3.22 \times 10^{-4}\right)\end{array}$ \\
\hline $\begin{array}{l}\text { Eurasian-American } \\
\text { Wigeon* } \\
\text { (Mareca penelope }-M \text {. } \\
\text { americana) }\end{array}$ & $\begin{array}{l}2,159.14 \\
(0.00)\end{array}$ & n.a. & $\begin{array}{c}38.74 \\
\left(3.87 \times 10^{-9}\right)\end{array}$ & $\begin{array}{c}74.20 \\
\left(7.72 \times 10^{-17}\right)\end{array}$ & $\begin{array}{l}3,791.54 \\
(0.00)\end{array}$ & $\begin{array}{c}1338.62 \\
\left(2.10 \times 10^{-291}\right)\end{array}$ & $\begin{array}{c}16.46 \\
\left(2.67 \times 10^{-4}\right)\end{array}$ & $\begin{array}{c}0.00 \\
(1.00)\end{array}$ \\
\hline $\begin{array}{l}\text { Northern Pintail } \\
(\text { Anas acuta) }\end{array}$ & $\begin{array}{c}459.55 \\
\left(1.62 \times 10^{-100}\right)\end{array}$ & $\begin{array}{c}637.26 \\
\left(4.17 \times 10^{-139}\right)\end{array}$ & $\begin{array}{c}0.00 \\
(1.00)\end{array}$ & $\begin{array}{c}30.12 \\
\left(2.88 \times 10^{-7}\right)\end{array}$ & $\begin{array}{c}893.17 \\
\left(1.13 \times 10^{-194}\right)\end{array}$ & $\begin{array}{c}260.84 \\
\left(2.29 \times 10^{-57}\right)\end{array}$ & $\begin{array}{c}124.40 \\
\left(9.69 \times 10^{-28}\right)\end{array}$ & $\begin{array}{c}219.34 \\
\left(2.35 \times 10^{-48}\right)\end{array}$ \\
\hline $\begin{array}{l}\text { Mallard } \\
\text { (Anas platyrhynchos) }\end{array}$ & $\begin{array}{c}327.92 \\
\left(6.21 \times 10^{-72}\right)\end{array}$ & $\begin{array}{c}1.96 .89 \\
\left(1.76 \times 10^{-43}\right)\end{array}$ & $\begin{array}{c}0.00 \\
(1.00)\end{array}$ & $\begin{array}{c}235.66 \\
\left(6.70 \times 10^{-52}\right)\end{array}$ & $\begin{array}{c}342.72 \\
\left(3.79 \times 10^{-75}\right)\end{array}$ & $\begin{array}{c}346.12 \\
\left(6.92 \times 10^{-76}\right)\end{array}$ & $\begin{array}{c}96.71 \\
\left(1.00 \times 10^{-21}\right)\end{array}$ & $\begin{array}{c}284.54 \\
\left(8.40 \times 10^{-26}\right)\end{array}$ \\
\hline $\begin{array}{l}\text { Greater Scaup } \\
(\text { Aythya marila) }\end{array}$ & $\begin{array}{c}42.82 \\
\left(5.03 \times 10^{-10}\right)\end{array}$ & $\begin{array}{c}79.81 \\
\left(6.40 \times 10^{-18}\right)\end{array}$ & $\begin{array}{c}0.00 \\
(1.00)\end{array}$ & $\begin{array}{l}9.36 \\
(0.01)\end{array}$ & $\begin{array}{c}246.94 \\
\left(2.39 \times 10^{-54}\right)\end{array}$ & $\begin{array}{c}54.94 \\
\left(1.17 \times 10^{-12}\right)\end{array}$ & $\begin{array}{l}1.99 \\
(0.37)\end{array}$ & $\begin{array}{l}2.00 \\
(0.17)\end{array}$ \\
\hline $\begin{array}{l}\text { Common Eider } \\
\text { (Somateria mollissima) }\end{array}$ & $\begin{array}{c}54.19 \\
\left(1.17 \times 10^{-12}\right)\end{array}$ & $\begin{array}{c}34.12 \\
\left(3.90 \times 10^{-8}\right)\end{array}$ & $\begin{array}{l}1.18 \\
(0.55)\end{array}$ & $\begin{array}{c}0.00 \\
(1.00)\end{array}$ & $\begin{array}{c}454.79 \\
\left(1.76 \times 10^{-99}\right)\end{array}$ & $\begin{array}{c}91.93 \\
\left(1.43 \times 10^{-20}\right)\end{array}$ & $\begin{array}{l}3.15 \\
(0.21)\end{array}$ & $\begin{array}{c}1.32 \\
(0.52)\end{array}$ \\
\hline
\end{tabular}


Table S4, continued.

\begin{tabular}{|c|c|c|c|c|c|c|c|c|}
\hline $\begin{array}{l}\text { Common-Wilson's Snipe } \\
\text { (Gallinago gallinago }-G \text {. } \\
\text { delicata) }\end{array}$ & $\begin{array}{c}2,071.15 \\
(0.00)\end{array}$ & $\begin{array}{c}363.60 \\
\left(1.11 \times 10^{-79}\right)\end{array}$ & $\begin{array}{c}14.16 \\
\left(8.44 \times 10^{-4}\right)\end{array}$ & $\begin{array}{c}0.00 \\
(1.00)\end{array}$ & $\begin{array}{c}756.97 \\
4.22 \times 10^{-165}\end{array}$ & $\begin{array}{c}194.24 \\
\left(6.64 \times 10^{-43}\right)\end{array}$ & $\begin{array}{c}5.65 \\
(0.06)\end{array}$ & $\begin{array}{c}321.58 \\
\left(1.48 \times 10^{-70}\right)\end{array}$ \\
\hline
\end{tabular}


Table S5. Raw demographic parameter output from $\delta a \delta i$ used to calculate biological estimates. The average of the best three runs from the best-fit model for each pairwise comparison is given with the $95 \%$ confidence interval around that parameter (in parentheses). Instances of a hyphen indicated that the parameter is not present in the best-fit model. These values were translated into biological estimates using values from Table S3. Translated values are given in Table S7. *Results from McLaughlin et al. (2020).

\begin{tabular}{|c|c|c|c|c|c|c|c|c|c|}
\hline $\begin{array}{l}\text { Pairwise comparison } \\
\text { (nu1 - nu2) }\end{array}$ & $\begin{array}{l}\text { Best fit model via } \\
\text { } \mathbf{a} \delta \mathbf{i}\end{array}$ & nu1 & nu2 & m12 & m21 & $\mathbf{m}$ & $\mathbf{T}$ & $\mathbf{T}_{\mathrm{sc}}$ & $\begin{array}{l}\text { Theta } \\
(\theta)\end{array}$ \\
\hline $\begin{array}{l}\text { Green-winged Teal* } \\
\text { (Anas crecca crecca-A. c. } \\
\text { carolinensis) }\end{array}$ & $\begin{array}{l}\text { secondary contact, } 2 \\
\text { migration } \\
\text { parameters }\end{array}$ & $\begin{array}{c}8.33 \\
( \pm 0.54)\end{array}$ & $\begin{array}{l}22.98 \\
( \pm 0.57)\end{array}$ & $\begin{array}{c}5.60 \\
( \pm 0.15)\end{array}$ & $\begin{array}{c}1.60 \\
( \pm 0.20)\end{array}$ & - & $\begin{array}{c}1.20 \\
( \pm 0.06)\end{array}$ & $\begin{array}{c}0.09 \\
( \pm 0.05)\end{array}$ & $\begin{array}{l}130.73 \\
( \pm 3.66)\end{array}$ \\
\hline $\begin{array}{l}\text { Long-tailed Duck* } \\
\text { (Clangula hyemalis) }\end{array}$ & $\begin{array}{l}\text { secondary contact, } 1 \\
\text { migration parameter }\end{array}$ & $\begin{array}{c}28.31 \\
( \pm 0.49)\end{array}$ & $\begin{array}{c}7.77 \\
( \pm 0.47)\end{array}$ & - & - & $\begin{array}{c}6.14 \\
( \pm 0.11)\end{array}$ & $\begin{array}{c}1.08 \\
( \pm 0.22)\end{array}$ & $\begin{array}{c}0.22 \\
( \pm 0.04)\end{array}$ & $\begin{array}{l}140.45 \\
( \pm 4.58)\end{array}$ \\
\hline $\begin{array}{l}\text { Eurasian-American Wigeon* } \\
\text { (Mareca penelope }-M \text {. } \\
\text { americana) }\end{array}$ & $\begin{array}{l}\text { secondary contact, } 2 \\
\text { migration } \\
\text { parameters }\end{array}$ & $\begin{array}{c}4.22 \\
( \pm 0.20)\end{array}$ & $\begin{array}{l}21.57 \\
( \pm 0.31)\end{array}$ & $\begin{array}{l}11.49 \\
( \pm 0.23)\end{array}$ & $\begin{array}{c}0.29 \\
( \pm 0.05)\end{array}$ & - & $\begin{array}{c}1.12 \\
( \pm 0.11)\end{array}$ & $\begin{array}{c}0.06 \\
( \pm 0.16)\end{array}$ & $\begin{array}{c}126.33 \\
( \pm 39.62)\end{array}$ \\
\hline $\begin{array}{l}\text { Northern Pintail } \\
(\text { Anas acuta })\end{array}$ & split with migration & $\begin{array}{c}11.96 \\
( \pm 0.59)\end{array}$ & $\begin{array}{c}44.67 \\
( \pm 1.56)\end{array}$ & - & - & $\begin{array}{c}17.45 \\
( \pm 0.02)\end{array}$ & $\begin{array}{c}1.35 \\
( \pm 0.06)\end{array}$ & - & $\begin{array}{l}31.04 \\
( \pm 1.18)\end{array}$ \\
\hline $\begin{array}{l}\text { Mallard } \\
\text { (Anas platyrhynchos) }\end{array}$ & split with migration & $\begin{array}{c}17.73 \\
( \pm 1.17)\end{array}$ & $\begin{array}{c}26.74 \\
( \pm 1.72)\end{array}$ & - & - & $\begin{array}{c}6.19 \\
( \pm 0.04)\end{array}$ & $\begin{array}{c}2.26 \\
( \pm 0.17)\end{array}$ & - & $\begin{array}{c}12.86 \\
( \pm 0.47)\end{array}$ \\
\hline $\begin{array}{l}\text { Greater Scaup } \\
(\text { Aythya marila) }\end{array}$ & split with migration & $\begin{array}{c}2.58 \\
( \pm 0.26)\end{array}$ & $\begin{array}{c}3.73 \\
( \pm 0.24)\end{array}$ & - & - & $\begin{array}{c}5.39 \\
( \pm 0.17)\end{array}$ & $\begin{array}{c}0.78 \\
( \pm 0.16)\end{array}$ & - & $\begin{array}{c}19.39 \\
( \pm 1.40)\end{array}$ \\
\hline $\begin{array}{l}\text { Common Eider } \\
\text { (Somateria mollissima) }\end{array}$ & $\begin{array}{l}\text { split with } \\
\text { bidirectional } \\
\text { migration }\end{array}$ & $\begin{array}{c}1.08 \\
( \pm 0.05)\end{array}$ & $\begin{array}{c}4.62 \\
( \pm 0.24)\end{array}$ & $\begin{array}{c}3.98 \\
( \pm 0.28)\end{array}$ & $\begin{array}{c}0.37 \\
( \pm 0.05)\end{array}$ & - & $\begin{array}{c}1.16 \\
( \pm 0.13)\end{array}$ & - & $\begin{array}{c}39.16 \\
( \pm 2.84)\end{array}$ \\
\hline $\begin{array}{l}\text { Common-Wilson's Snipe } \\
\text { (Gallinago gallinago }-G \text {. } \\
\text { delicata) }\end{array}$ & $\begin{array}{l}\text { split with } \\
\text { bidirectional } \\
\text { migration }\end{array}$ & $\begin{array}{c}2.57 \\
( \pm 0.13)\end{array}$ & $\begin{array}{l}16.10 \\
( \pm 0.57)\end{array}$ & $\begin{array}{c}0.001 \\
( \pm 0.006)\end{array}$ & $\begin{array}{c}0.53 \\
( \pm 0.03)\end{array}$ & - & $\begin{array}{c}1.47 \\
( \pm 0.09)\end{array}$ & - & $\begin{array}{c}165.61 \\
( \pm 10.13)\end{array}$ \\
\hline
\end{tabular}


Table S6. Biological estimates obtained from the best-fit $\delta a \delta i$ models for each pairwise comparison. Here we report, as appropriate for each model, ancestral population size ( $N_{\text {ref }}$, in number of individuals), size of population 1 ( $N_{e}$ or $n u 1$, in number of individuals), size of population 2 ( $N_{e}$ or $n u 2$, in number of individuals), migration (gene flow) from population 1 into population 2 ( $m 12$ as individuals/generation), migration from population 2 into population 1 ( $m 21$, individuals/generation), time since split ( $T$, in years), and time of secondary contact ( $T_{s c}$, in years). Values in parenthesis are the $\pm 95 \%$ confidence interval around the biological estimates.

*Results from McLaughlin et al. (2020).

\begin{tabular}{|c|c|c|c|c|c|c|c|c|}
\hline $\begin{array}{l}\text { Pairwise comparison } \\
\text { (nu1 - nu2) }\end{array}$ & $\begin{array}{l}\text { Best fit model via } \\
\delta \mathbf{a} \delta \mathbf{i}\end{array}$ & $\mathbf{N}_{\text {ref }}$ & $\mathbf{N}_{\mathrm{e}}$ (nu1) & $\mathrm{N}_{\mathrm{e}}$ (nu2) & $\begin{array}{l}\text { Migration } \\
\text { (m12) }\end{array}$ & $\begin{array}{l}\text { Migration } \\
\text { (m21) }\end{array}$ & $\begin{array}{l}\text { Time } \\
\text { since split } \\
\quad(T)\end{array}$ & $\begin{array}{l}\text { Time of } \\
\text { secondary } \\
\text { contact } \\
\text { (s) }\end{array}$ \\
\hline $\begin{array}{l}\text { Green-winged Teal* } \\
\text { (Anas crecca crecca-A.c. } \\
\text { carolinensis) }\end{array}$ & $\begin{array}{l}\text { secondary contact, } 2 \\
\text { migration parameters }\end{array}$ & $\begin{array}{c}70,305 \\
( \pm 1,967)\end{array}$ & $\begin{array}{l}1,615,683 \\
( \pm 39,884)\end{array}$ & $\begin{array}{c}585,290 \\
( \pm 38,181)\end{array}$ & $\begin{array}{c}23.31 \\
( \pm 0.63)\end{array}$ & $\begin{array}{l}18.35 \\
( \pm 2.29)\end{array}$ & $\begin{array}{c}277,048 \\
( \pm 12,993)\end{array}$ & $\begin{array}{c}21,092 \\
( \pm 10,979)\end{array}$ \\
\hline $\begin{array}{l}\text { Long-tailed Duck* } \\
\text { (Clangula hyemalis) }\end{array}$ & $\begin{array}{l}\text { secondary contact, } 1 \\
\text { migration parameter }\end{array}$ & $\begin{array}{l}15,054 \\
( \pm 491)\end{array}$ & $\begin{array}{l}116,892 \\
( \pm 7,075)\end{array}$ & $\begin{array}{l}426,144 \\
( \pm 7,410)\end{array}$ & $\begin{array}{c}23.835 \\
( \pm 0.430)\end{array}$ & $\begin{array}{c}86.892 \\
( \pm 1.569)\end{array}$ & $\begin{array}{c}163,001 \\
( \pm 32,981)\end{array}$ & $\begin{array}{c}33,600 \\
( \pm 5,564)\end{array}$ \\
\hline $\begin{array}{l}\text { Eurasian-American Wigeon* } \\
\text { (Mareca penelope }-M \text {. } \\
\text { americana) }\end{array}$ & $\begin{array}{l}\text { secondary contact, } 2 \\
\text { migration parameters }\end{array}$ & $\begin{array}{c}27,138 \\
( \pm 8,512)\end{array}$ & $\begin{array}{l}114,519 \\
( \pm 5,546)\end{array}$ & $\begin{array}{l}585,272 \\
( \pm 8,365)\end{array}$ & $\begin{array}{c}24.241 \\
( \pm 0.481)\end{array}$ & $\begin{array}{c}3.173 \\
( \pm 0.562)\end{array}$ & $\begin{array}{c}166,395 \\
( \pm 15,777)\end{array}$ & $\begin{array}{c}8,848 \\
( \pm 23,974)\end{array}$ \\
\hline $\begin{array}{l}\text { Northern Pintail } \\
(\text { Anas acuta) }\end{array}$ & split with migration & $\begin{array}{c}32,825 \\
( \pm 1,246)\end{array}$ & $\begin{array}{c}392,468 \\
( \pm 19,445)\end{array}$ & $\begin{array}{l}1,466,348 \\
( \pm 51,272)\end{array}$ & $\begin{array}{ll}8 & 104.32 \\
& ( \pm 0.14)\end{array}$ & $\begin{array}{l}389.78 \\
( \pm 0.53)\end{array}$ & $\begin{array}{c}287,213 \\
( \pm 12,254)\end{array}$ & - \\
\hline $\begin{array}{l}\text { Mallard } \\
\text { (Anas platyrhynchos) }\end{array}$ & split with migration & $\begin{array}{c}28,881 \\
( \pm 1,063)\end{array}$ & $\begin{array}{c}512,003 \\
( \pm 33,698)\end{array}$ & $\begin{array}{c}772,228 \\
( \pm 49,706)\end{array}$ & $\begin{array}{c}54.83 \\
( \pm 0.31)\end{array}$ & $\begin{array}{c}82.70 \\
( \pm 0.47)\end{array}$ & $\begin{array}{c}333,304 \\
( \pm 24,622)\end{array}$ & - \\
\hline $\begin{array}{l}\text { Greater Scaup } \\
\text { (Aythya marila) }\end{array}$ & split with migration & $\begin{array}{c}5,904 \\
( \pm 426)\end{array}$ & $\begin{array}{c}15,233 \\
( \pm 1,509)\end{array}$ & $\begin{array}{c}22,016 \\
( \pm 1,437)\end{array}$ & $\begin{array}{c}6.96 \\
( \pm 0.22)\end{array}$ & $\begin{array}{c}10.06 \\
( \pm 0.32)\end{array}$ & $\begin{array}{c}36,886 \\
( \pm 7,541)\end{array}$ & - \\
\hline
\end{tabular}


Table S6, continued.

\section{Common Eider}

(Somateria mollissima)

Common-Wilson's Snipe

(Gallinago gallinago - $G$.

delicata) split with

bidirectiona

migration

$23,458 \quad 25,267 \quad 108,479$

$( \pm 1,700) \quad( \pm 1,104)$

$( \pm 5,631)$

2.14

0.86

505,517

split with

bidirectional

$32,998 \quad 531,303$

84,815

0.01

0.68

193,021

migration 
Figure S1. Models of divergence tested using $\delta a \delta i$ (Gutenkunst et al., 2009) to determine demographic histories between populations: A) neutral, no divergence; B) split with no migration; C) split with migration, 1 migration parameter (i.e., bidirectionally symmetric); D) split with bidirectional migration, 2 migration parameters (i.e., bidirectionally asymmetric); E) split with exponential population growth, no migration; F) split with exponential population growth and migration; G) secondary contact with migration (1 migration parameter); and $\mathbf{H}$ ) secondary contact with bidirectional migration (2 migration parameters). Models that contain one arrow indicate gene flow at relatively equal levels, while models with two arrows indicate unequal levels of gene flow (asymmetric). The gradient of contrast illustrates increasing population differentiation.

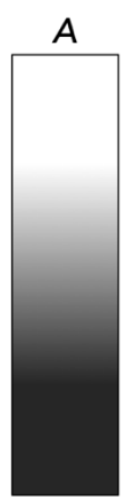

E

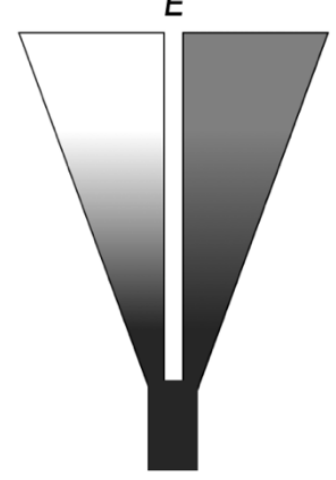

B

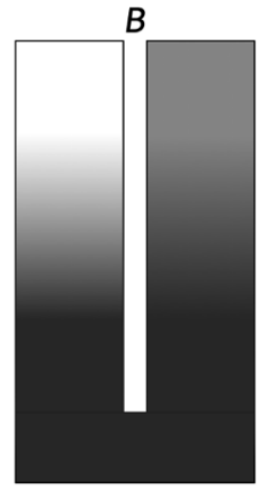

F

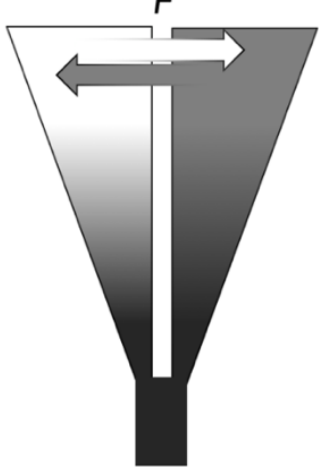

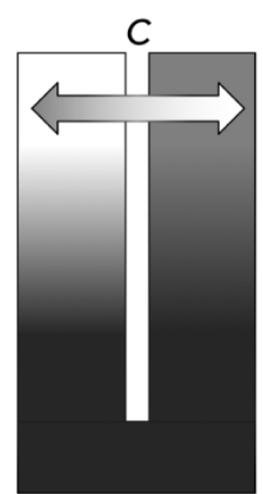

G

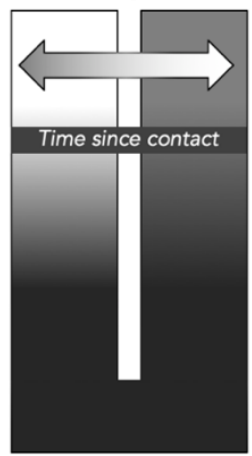

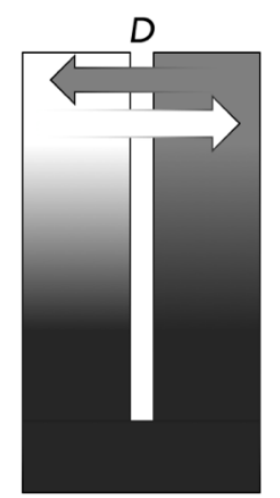

H

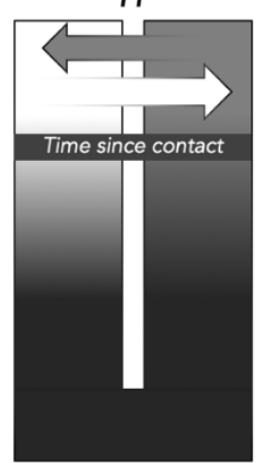

